The University of Maine

\title{
DigitalCommons@UMaine
}

Earth Science Faculty Scholarship

Earth Sciences

$1-7-2004$

\section{Surface Deformations as Indicators of Deep Ebullition Fluxes in a Large Northern Peatland}

P. H. Glaser

J.P. Chanton

P. Morin

D. O. Rosenberry

D. I. Siegel

See next page for additional authors

Follow this and additional works at: https://digitalcommons.library.umaine.edu/ers_facpub Part of the Earth Sciences Commons

\section{Repository Citation}

Glaser, P. H.; Chanton, J. P.; Morin, P.; Rosenberry, D. O.; Siegel, D. I.; Ruud, O.; Chasar, L. I.; and Reeve, Andrew S., "Surface Deformations as Indicators of Deep Ebullition Fluxes in a Large Northern Peatland" (2004). Earth Science Faculty Scholarship. 95. https://digitalcommons.library.umaine.edu/ers_facpub/95 
Authors

P. H. Glaser, J. P. Chanton, P. Morin, D. O. Rosenberry, D. I. Siegel, O. Ruud, L. I. Chasar, and Andrew S. Reeve 


\title{
Surface deformations as indicators of deep ebullition fluxes in a large northern peatland
}

\author{
P. H. Glaser, ${ }^{1}$ J. P. Chanton, ${ }^{2}$ P. Morin, ${ }^{1}$ D. O. Rosenberry, ${ }^{3}$ D. I. Siegel, ${ }^{4}$ O. Ruud, ${ }^{5}$ \\ L. I. Chasar, ${ }^{2,6}$ and A. S. Reeve ${ }^{7}$ \\ Received 19 March 2003; revised 20 August 2003; accepted 23 October 2003; published 7 January 2004.
}

[1] Peatlands deform elastically during precipitation cycles by small $( \pm 3 \mathrm{~cm})$ oscillations in surface elevation. In contrast, we used a Global Positioning System network to measure larger oscillations that exceeded $20 \mathrm{~cm}$ over periods of 4-12 hours during two seasonal droughts at a bog and fen site in northern Minnesota. The second summer drought also triggered 19 depressuring cycles in an overpressured stratum under the bog site. The synchronicity between the largest surface deformations and the depressuring cycles indicates that both phenomena are produced by the episodic release of large volumes of gas from deep semi-elastic compartments confined by dense wood layers. We calculate that the three largest surface deformations were associated with the release of $136 \mathrm{~g} \mathrm{CH}_{4}$ $\mathrm{m}^{-2}$, which exceeds by an order of magnitude the annual average chamber fluxes measured at this site. Ebullition of gas from the deep peat may therefore be a large and previously unrecognized source of radiocarbon depleted methane emissions from northern peatlands. INDEX TERMS: 0315 Atmospheric Composition and Structure: Biosphere/ atmosphere interactions; 1615 Global Change: Biogeochemical processes (4805); 1829 Hydrology: Groundwater hydrology; 1890 Hydrology: Wetlands; KEYWORDS: ebullition, methane, peatlands

Citation: Glaser, P. H., J. P. Chanton, P. Morin, D. O. Rosenberry, D. I. Siegel, O. Ruud, L. I. Chasar, and A. S. Reeve (2004), Surface deformations as indicators of deep ebullition fluxes in a large northern peatland, Global Biogeochem. Cycles, 18, GB1003, doi:10.1029/2003GB002069.

\section{Introduction}

[2] Northern peatlands are both an important source and sink for greenhouse gases, but the present carbon balance of these ecosystems and their response to climatic change remains uncertain [Gorham, 1991]. At present the carbon fluxes from the upper aerobic layer (acrotelm) of peat are much better documented than those from the deeper anoxic strata (catotelm), where more than $90 \%$ of the carbon mass is stored. Measurements of methane and carbon dioxide fluxes in the catotelm are largely based on the dissolved phases of these greenhouse gases or on destructive laboratory incubations [e.g., Wieder et al., 1990; Yavitt and Lang, 1990; Yavitt et al., 1997; Romanowicz et al., 1993, 1995;

\footnotetext{
${ }^{1}$ Department of Geology and Geophysics, University of Minnesota, Minneapolis, Minnesota, USA.

${ }^{2}$ Department of Oceanography, Florida State University, Tallahassee, Florida, USA.

${ }^{3}$ Water Resources Division, U.S. Geological Survey, Lakewood, Colorado, USA.

${ }^{4}$ Department of Earth Sciences, Syracuse University, Syracuse, New York, USA.

${ }^{5}$ UNAVCO, Boulder, Colorado, USA.

${ }^{6}$ Now at District Office, U.S. Geological Survey, Tallahassee, Florida, USA.

${ }^{7}$ Department of Geological Sciences, University of Maine, Orono, Maine, USA.

Copyright 2004 by the American Geophysical Union. 0886-6236/04/2003GB002069
}

Waddington and Roulet, 1997; Clymo and Pearce, 1995; Bridgham et al., 1998]. The free-phase forms of these greenhouse gases are more difficult to quantify because of the buoyancy, discontinuous distribution, and phase instability of gas bubbles in saturated porous media [Freeze and Cherry, 1979; Ingebritsen and Sanford, 1998]. As a result, some controversy exists over the abundance of free-phase gas in the catotelm and its significance as a source for greenhouse gas emissions from peatlands.

[3] Recently, Fechner-Levy and Hemond [1996] calculated the mass of free-phase gas in the floating mat of Thoreau's bog by monitoring topographic oscillations of the peat surface with a custom level-meter. They determined that the mass of methane partitioned into bubbles within the mat may be 3 times greater than that in the dissolved phase. Small topographic oscillations have previously been reported on a wide range of peat deposits, but these deformations were generally considered to be a response to changes in water storage or freeze-thaw cycles [Ingram, 1983]. However, Almendinger et al. [1986] reported vertical oscillations greater than $10 \mathrm{~cm}$ in the Lost River peatland of northern Minnesota that were associated with climatedriven reversals in hydraulic head at depth. The Lost River bog also had an unexpected zone of overpressure at $1 \mathrm{~m}$ depth [Siegel and Glaser, 1987], suggesting that the abnormal pressures and surface deformations could be produced by changing bubble volumes in the catotelm. To test this hypothesis, we instrumented a bog and adjacent fen site in 


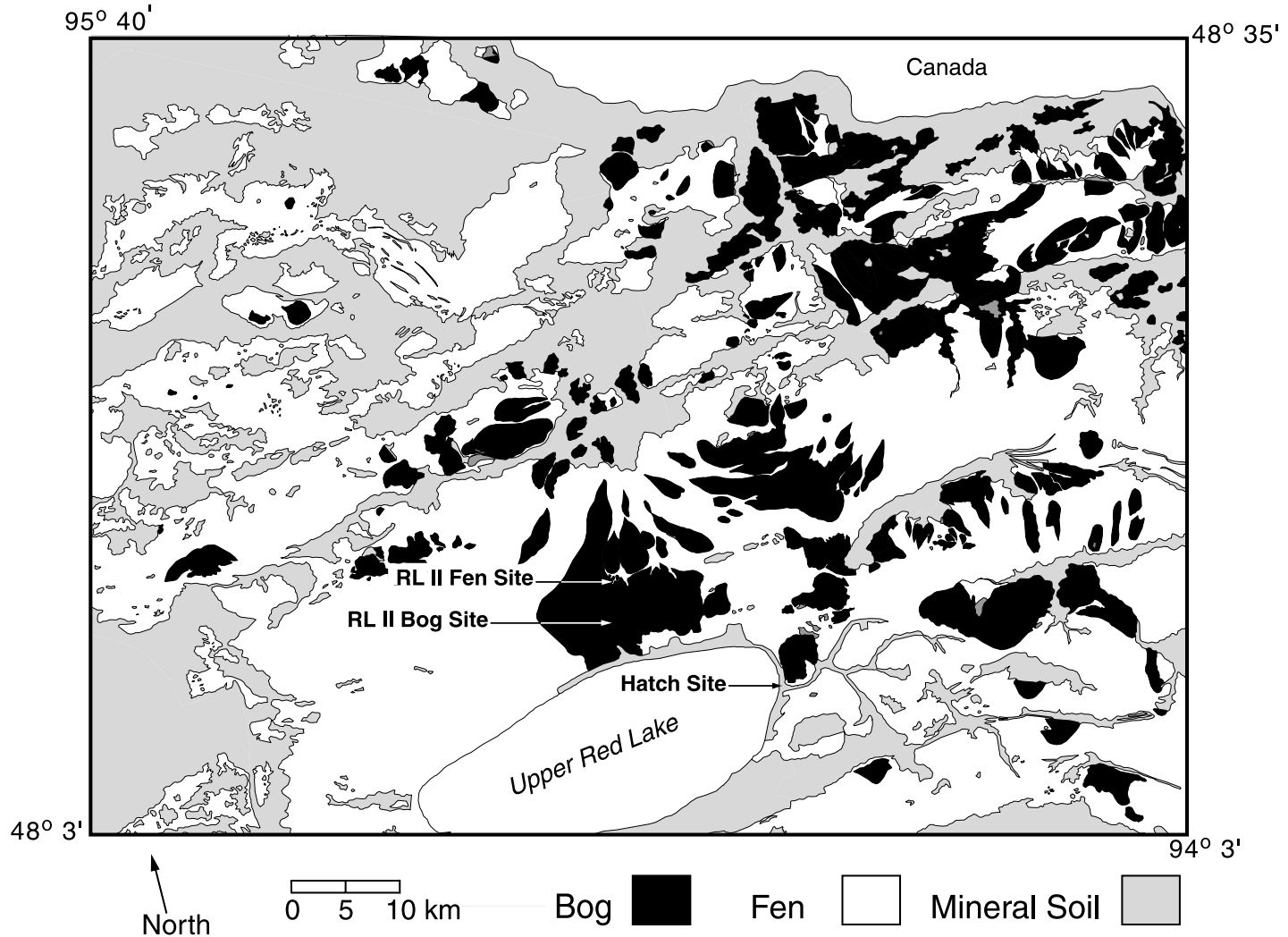

Figure 1. Map of the Glacial Lake Agassiz peatlands in northern Minnesota with the location of the three instrument stations. Redrawn from Glaser [1992] and Glaser et al. [1997].

the Red Lake peatland of northern Minnesota to monitor synchronous changes in surface elevation and peat-pore pressures in relation to other environmental factors.

\section{Materials and Methods}

\subsection{Study Area}

[4] The study area is located within the Glacial Lake Agassiz peatlands (GLAP) of northern Minnesota (Figure 1). The regional landscape is dominated by a nearly flat lake plain, which has a gradient of less than $20 \mathrm{~cm}$ per kilometer [Wright, 1972]. Peatlands cover nearly $5000 \mathrm{~km}^{2}$ of this region, forming large expanses that are only locally interrupted by sandy beach deposits or areas of ground moraine [Glaser, 1992]. Peatlands began forming in this region after $5000 \mathrm{yr}$ B.P. and now average about $2-3 \mathrm{~m}$ in depth. The most striking features of peatland development are bog and fen landforms that are most highly developed within the Red Lake peatland [Glaser et al., 1981] (Figure 1). These landforms accumulated under an unusually dry regional climate marked by only a slight surplus of precipitation over evapotranspiration and periodic droughts of varying intensity and duration [Baker et al., 1967, 1979, 1985].

[5] Instrument stations were established in the central watershed (watershed II of Glaser et al. [1981]) of the $1200 \mathrm{~km}^{2}$ Red Lake peatland (Figure 1). The bog station is located at the crest of a $150 \mathrm{~km}^{2}$ raised bog, whereas the fen station is located $3 \mathrm{~km}$ downslope at the head of a $17 \mathrm{~km}^{2}$ system of fen water tracks that divide the lower flanks of the bog into ovoid bog islands. The bog site has an open stand of Picea mariana (black spruce), an understory of ericaceous shrubs, and a nearly continuous mat of Sphagnum angustifolium, S. magellanicum, S. fuscum, and S. capillifolium (relevé 24 of Glaser et al. [1981]). The surface waters are acidic $(\mathrm{pH}<4.2)$ with low concentrations of inorganic solutes (e.g., calcium $<2 \mathrm{mg} \mathrm{L}^{-1}$ ). The fen site, in contrast, is a nonforested sedge lawn studded with small circular tree islands. The sedge lawn is dominated by Carex lasiocarpa, C. limosa, C. livida, Rhynchospora alba, and R. fusca (relevés 4 and 5 of Glaser et al. [1981]), whereas the tree islands have open stands of black spruce (Picea mariana), tamarack (Larix laricina), ericaceous shrubs, and a few fen indicators such as Betula pumila var. glandulifera, Carex chordorrhiza, C. canescens, and C. tenuiflora (relevé 6 of Glaser et al. [1981]). The standing water in the sedge lawn has a higher $\mathrm{pH}(6-6.5)$ and calcium concentration $(5.8 \mathrm{mg}$ $\left.\mathrm{L}^{-1}\right)$ than the pore waters from pits in the circular islands $(\mathrm{pH}$ 4.3-4.4; Ca concentration 3.2-4.8 $\mathrm{mg} \mathrm{L}^{-1}$ ). The bog site is underlain by $4.3 \mathrm{~m}$ of peat with dense wood layers between depths of 2-3 $\mathrm{m}$ (Figure 2). The fen site in contrast is underlain by $3 \mathrm{~m}$ of peat with wood layers under the tree islands [Janssens et al., 1992; P. H. Glaser, unpublished data, 1993].

\subsection{Hydrogeology and Weather Stations}

[6] The hydrogeology stations were installed in a small clearing at the bog site and in a sedge-dominated lawn at the 


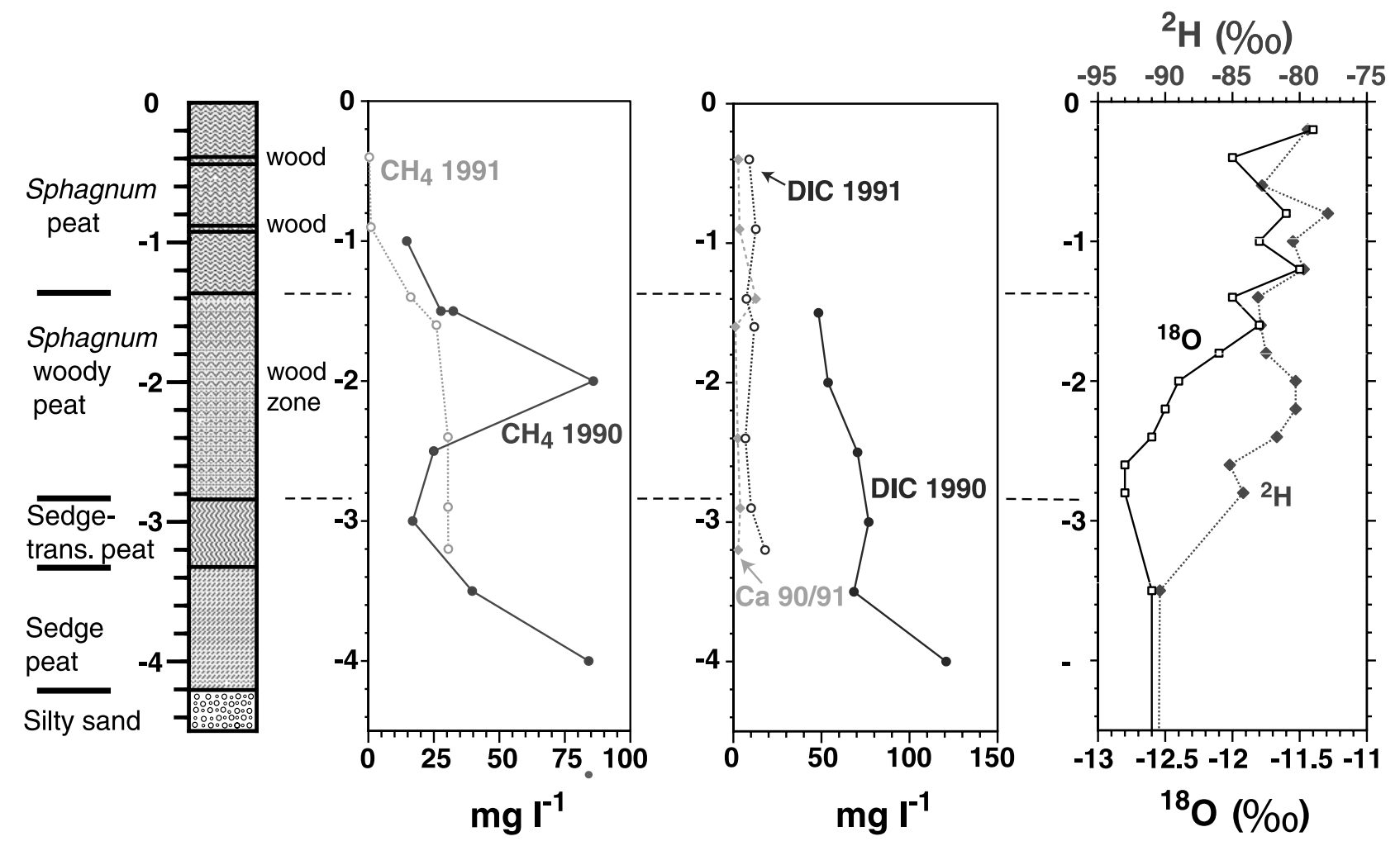

Figure 2. Peat stratigraphy at the Red Lake II bog site with respect to pore water concentration of dissolved methane, dissolved inorganic carbon (DIC), deuterium, and ${ }^{18} \mathrm{O}$. High values for methane and DIC occurred in a zone of woody Sphagnum peat below $1 \mathrm{~m}$ depth during an extreme drought in 1990 [Romanowicz et al., 1995; Glaser et al., 1997]. The deeper pore waters are also enriched in deuterium relative to ${ }^{18} \mathrm{O}$, indicating high rates of methanogenesis [Siegel et al., 2001]. All depths are presented relative to the peat surface. See color version of this figure at back of this issue.

fen site near a small circular tree island. Piezometers (3.5cm-diameter PVC) were installed at 1, 2, and $3 \mathrm{~m}$ depths below the peat surface at each site according to methods described by Siegel and Glaser [1987] and Romanowicz et al. [1993]. The piezometers were connected to a stable platform anchored to the glacial deposits beneath the peat, and were surveyed to a common datum at each site. Vented 69or $34.5-\mathrm{kPa}$ submersible pressure transducers were placed inside the piezometers and connected to a digital data logger to provide hydraulic head with a resolution of $0.01 \mathrm{~cm}$ and an accuracy of $0.5 \mathrm{~cm}$ or better. Pressure-transducer output was converted to hydraulic head relative to the peat surface (set as a fixed elevation relative to the instrument platform). Fieldcheck measurements were made during each monthly visit during the summer of 1997. Sensor drift was minimal; all but three check measurements were within $1 \mathrm{~cm}$ of true values. Precipitation data were collected through the summer of 1997 with a tipping-bucket rain gage located at the Hatch site in Waskish (Figure 1), $16 \mathrm{~km}$ southeast of the bog site. In addition, the bog station collected other environmental data including barometric pressure, wind speed, wind direction, and both ambient and peat temperatures to $4 \mathrm{~m}$ depth.

\subsection{Global Positioning System Network}

[7] During the summer of 1997, we established 3 Global Positioning System (GPS) base stations to determine the magnitude and periodicity of vertical fluctuations in the land surface in the Red Lake peatland. First, a fixed (static) control station was installed on mineral uplands at the periphery of the peatland. This static GPS station (Hatch site in Figure 1) was tied to a local National Geodetic Survey (NGS) control point, which was located less than $1.6 \mathrm{~km}$ away. A second static GPS station was installed at the bog crest in the central watershed of the Red Lake peatland, and a third static GPS station was installed on a circular tree island at the fen site approximately $3 \mathrm{~km}$ farther downslope. This station could not be installed directly in the sedge-dominated fen because no trees were available for mounting the GPS antenna. Both the bog and fen GPS stations, however, were located within $30 \mathrm{~m}$ of the hydrogeology stations.

[8] The GPS antennas for the peatland base stations were securely mounted to tree trunks to monitor vertical fluctuations in the peat surface. The antennas were bolted to a small wooden platform built on top of a stout tree trunk that was truncated at $2 \mathrm{~m}$ height and stripped of its lateral branches. The trees are anchored by spreading root systems providing a stable and minimally intrusive platform. The antennas were connected by armored cables to Trimble 4000 SSI GPS receivers powered by solar panels and deep-cycle marine batteries. Each of the GPS units was originally programmed to record a 1-hour survey-session every 6 hours (4 sessions/day). These same units were later 
re-programmed to record a 20-min session every 2 hours (12 sessions/day) between August 14 and September 13, 1997. The stability of the base station on mineral soil was tested by several continuous 24-hour GPS surveys between the Hatch station and the local geodetic monument.

[9] Double differencing (simultaneously tracking four or more GPS satellites with two or more GPS receivers) was used to eliminate systematic errors related to the satellites (e.g., orbital or clock biases) or receivers (e.g., clock errors) [Hofmann-Wellenhof et al., 1997]. Errors caused by ionosphere refraction were eliminated by the use of dualfrequency GPS receivers, whereas multipath errors were mitigated by antenna ground planes. Residual errors due to multipath (i.e., multiple signal reflections), troposphere refraction, or antenna phase-center variation limit the vertical accuracy of a survey to $1 \mathrm{~cm}+1 \mathrm{ppm}$ of the baseline $(16 \mathrm{~km})$ and limit the horizontal accuracy to several millimeters specified for the Trimble 4000 SSI receivers. The entire GPS data set was post-processed using GPSurvey software, but solutions for critical time intervals were also verified with the Bernese processing software.

\subsection{Wavelet Analysis}

[10] The late-summer GPS and pore pressure data were analyzed by wavelet analysis using the method described by Torrence and Compo [1998]. Wavelet analysis decomposes a time series into time-frequency space to determine both the dominant modes of variability and how these modes vary across a time series. The resulting wavelet power spectra provide a measure of time series variance at each period and at each location along the time series. The latesummer time series for peat-surface elevations and bog pore pressures at $2 \mathrm{~m}$ depth were compared with the Morlet wavelet, which produced qualitatively similar results to those obtained with the Paul and Mexican-hat waveforms. Each time series was padded with zeros to minimize wraparound effects, and the wavelet function was normalized to ensure that the wavelet transforms at each scale are directly comparable to each other and to the transforms of other time series. A red noise background spectrum was used to determine significance levels for non-stationary variance.

\section{Results}

\subsection{Weather}

[11] Two dry periods occurred during the growing season of 1997. The first period extended from early May to June 23, whereas the second occurred between August 18 and September 16. Rainfall was also sporadic during a 24-day period between July 25 and August 18. Precipitation never exceeded $1 \mathrm{~cm}$ within a 24-hour period during the entire summer of 1997 except for three large rain events on June 27, July 25, and September 16. During the summer, wind speed generally followed a diurnal cycle, with nearly calm conditions prevailing at night.

\subsection{Surface Deformations}

[12] Both the hourly (4/day) and 20-min (12/day) GPS surveys recorded significant oscillations of the peat surface at the bog and fen sites. The average 4-day trend for the 1-hour GPS surveys generally corresponded to changes in precipitation and local water table elevations. The peat surface, for example, gradually subsided at both sites toward the end of an early summer dry period between June 17 to June 23 (Figure 3). This dry period, however, was also marked by several large elastic deformations in which the peat surface abruptly rose and fell by $15 \mathrm{~cm}$ in an 18-hour period at the bog site and $32 \mathrm{~cm}$ in an 18-hour period at the fen site. These large vertical displacements were often associated with significant horizontal oscillations of 8 to $13 \mathrm{~cm}$ in 12 hours at the bog site and 13 to $25 \mathrm{~cm}$ in 12 hours at the fen site (Figure 4). However, several large horizontal displacements occurred at both sites that were not associated with corresponding vertical displacements.

[13] The amplitude of these abrupt surface deformations generally decreased after the first dry period ended on June 23 and the water table began rising. The peat surface subsequently rose gradually when precipitation produced rising water tables, and then it subsided as the water table fell in response to evapotranspirational losses or runoff. The response was consistently greater at the fen site, which also tended to lag slightly behind the timing of elevational trends at the bog. Toward the end of the hourly surveys (July 26 to August 13), the peat surface at both sites again began subsiding, with large short-term oscillations at the fen site.

[14] The 20-min surveys (every 2 hours) monitored higher-frequency oscillations, particularly during a latesummer drought between August 16 and September 16, 1997 (Figure 5). The water table fell continuously during this period, but the peatland GPS stations recorded significant vertical oscillations for both the short 2-hour sampling intervals and the longer-term interval of the 4-day moving average. Both the bog and fen surface gradually subsided from August 16 to 30 , but then they rose by about $2-3 \mathrm{~cm}$ over 4 days before falling again. These gradual trends in surface elevation closely followed the 4-day moving average for atmospheric pressure (Figure 6).

[15] The shorter-term oscillations of the peat surface, in contrast, had a much higher amplitude, particularly at the bog site. Three exceptionally large deformations occurred at the bog site in late summer on August 29, September 4, and September 13, when the peat surface fell and then sprang back for a total vertical displacement of over $20 \mathrm{~cm}$ within a 4-hour period. Significant net vertical displacements of $10 \mathrm{~cm}$ or more within a 4-hour period were also common. Similar large $(>20 \mathrm{~cm} / 4$ hour $)$ but asynchronous vertical oscillations occurred at the fen site on August 30 and September 1. During other periods the bog and fen oscillations were in phase, including a large oscillation on September 13. A data hiatus then occurred at the fen instrument stations after September 13, when exposed cables were severed by gnawing animals.

[16] Two dominant frequency modes were apparent in the GPS time series from August 13 to September 14, 1997 (Figure 7). The non-stationary variance is localized into discrete zones that correspond to the largest surface displacements. The Morlet power spectra identified irregularly occurring cycles with a period of $4-8$ hours and more diffuse cycles with 16-32 hour periods The most intense 4-8 hour cycles were generally out of phase at the bog and 


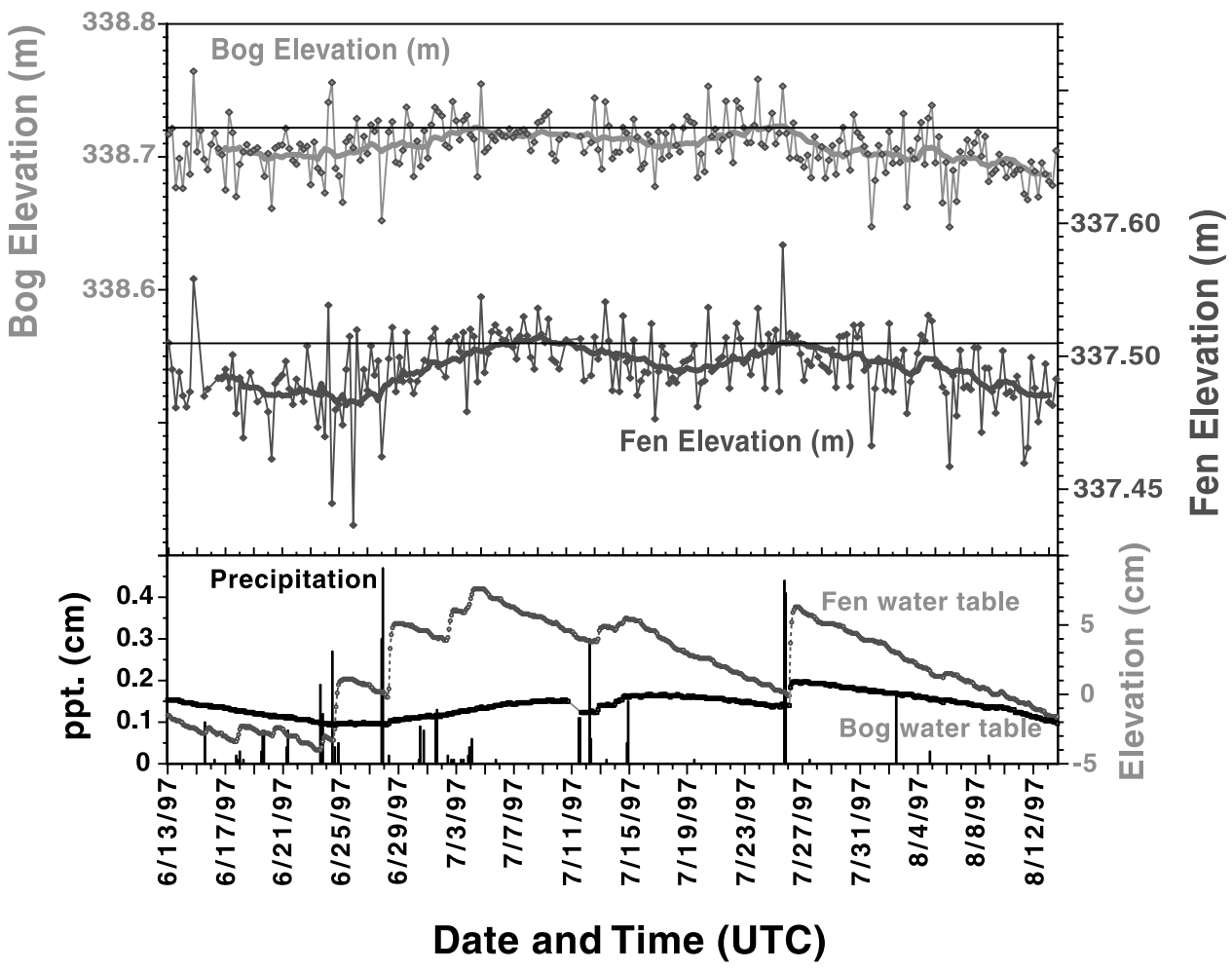

Figure 3. Surface elevations of the Red Lake bog and fen site during an early summer drought cycle. Periods with minimal precipitation and falling water tables were associated with (1) high amplitude topographic oscillations (diamonds indicate solutions to the hourly GPS surveys recorded every 6 hours) and (2) gradual decline in the average surface elevation (thick line indicates 4-day moving average). The GPS elevations are plotted relative to a horizontal line indicating the initial survey elevation. The bottom panel shows precipitation (bars) recorded at the Hatch site and water table elevations recorded at the bog and fen sites. Note the 18-hour data hiatus for the bog water table on July 9-10. See color version of this figure at back of this issue.

fen sites except for the major oscillation on September 13. However, the overall distribution of non-stationary variance at the bog and fen sites was different.

\subsection{Peat Pore Pressure and Hydraulic Head}

[17] The pore pressure and calculated hydraulic head gradients were different at the bog and fen sites [Rosenberry et al., 2003]. At the sedge-fen site, hydraulic head consistently increased from 1 to $3 \mathrm{~m}$ depth. The head response of the three piezometers was coherent at each depth, rising quickly after rainfall events and then declining gradually until the next rainfall. The calculated head at $1 \mathrm{~m}$ depth was assumed to indicate the fluctuation of the water table. At the bog site, however, the piezometers at 1,2, and $3 \mathrm{~m}$ depth did not respond coherently to precipitation events (Figure 8). The piezometer at $1 \mathrm{~m}$ depth rose rapidly after each rainfall and then gradually declined until the next rainfall (Figures 3 and 8). At $3 \mathrm{~m}$ depth, however, hydraulic head fluctuated inversely with changes in atmospheric pressure (Figure 9), indicating the existence of a hydraulic confining layer in the peat profile [Freeze and Cherry, 1979, pp. 232-234; Domenico and Schwartz, 1990, pp. 128-130].

[18] The bog profile also contained a zone of overpressure at $2 \mathrm{~m}$ depth that persisted for the entire 5 -year period of measurements. The head at $2 \mathrm{~m}$ stabilized at approximately $8-10 \mathrm{~cm}$ higher than the head at $1 \mathrm{~m}$, but it then declined toward the end of the late summer drought in 1997 (Figure 8). This trend was punctuated by 19 short depressuring cycles in which the hydraulic head fell by $5-7 \mathrm{~cm}$ within a 6-hour period before recovering to the former high levels. Similar short depressuring cycles were not recorded at the fen site nor at the 1- or 3-m piezometers at the bog site.

[19] The wavelet power spectrum for late-summer overpressure at the bog site is shown in Figure 7. The nonstationary variance is localized into zones of high power with a period of $8-16$ hours and in more diffuse zones of lower power with longer periods up to 32 hours. The $8-16$ hour cycles occur irregularly across the time series and are generally in phase with the short-period cycles of the bog GPS data but not that of the fen. The non-stationary variance was very unevenly distributed across the power spectra, particularly within the first half of the time series.

\subsection{Ebullition Fluxes}

[20] The largest depressuring cycles at the bog site occurred nearly synchronously with large vertical oscillations of the peat surface (Figures 5, 7, 8, and 10). The depressuring cycles continued throughout the drought and 

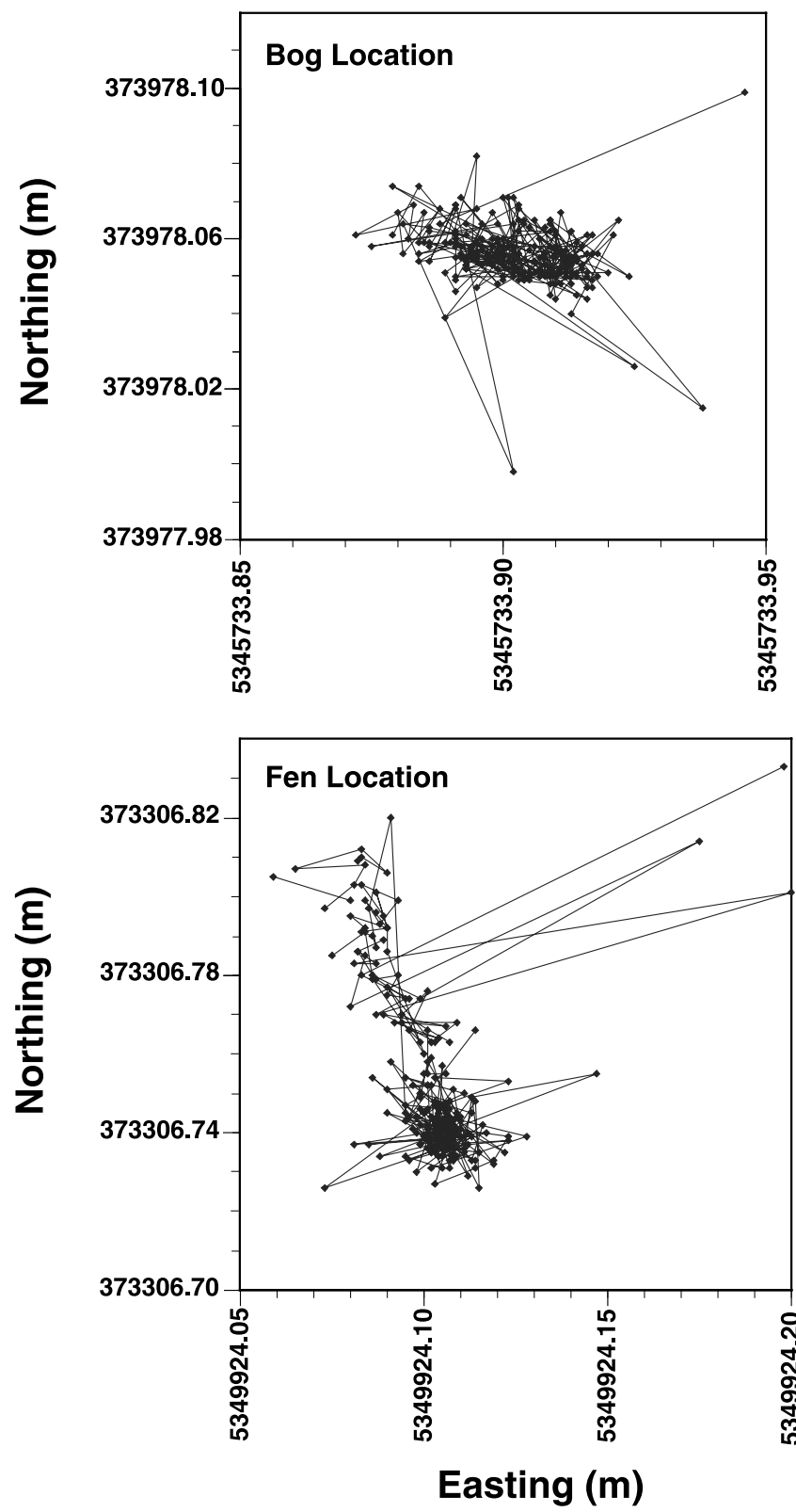

Figure 4. Horizontal surface displacements at the Red Lake bog and fen sites. Each symbol indicates the solution to an hourly GPS survey recorded every 6 hours from June 13 to August 14. The data sets contain several missing values. The GPS positions are plotted by their Universal Transverse Mercator (UTM) coordinates. See color version of this figure at back of this issue.

included three major events during which the bog surface rose and fell by more than $20 \mathrm{~cm}$ in 4 hours. The minima of these three topographic oscillations were nearly synchronous with the nadirs of the largest depressuring events recorded by the pressure transducers as shown for the event on September 13, 1997 (Figure 10). During each of these events the peat surface first rose by a few centimeters and then dramatically dropped by $9-16 \mathrm{~cm}$ in 2 hours before quickly springing back up by $8-12 \mathrm{~cm}$. This elastic response indicates the rise of a bubble mass to the peat surface, the collapse of the bubble mass during degassing to the atmosphere, and the elastic rise of the peat surface as pore water moves horizontally to fill the voids left by the collapsed bubbles.

[21] No other explanation for these elevational changes is likely because changes in hydraulic head in granular media are usually associated with much smaller elevational oscillations (e.g., $10 \mathrm{~m}$ of head change produces only $1 \mathrm{~cm}$ elevation change [Freeze and Cherry, 1979]. Peat, however, has a much higher degree of elastic response to a multiphase flow because of its very high water content. In addition, the transient release of peat pore water driven by climatic fluctuations [Waddington, 1995; Devito et al., 1997; Waddington and Roulet, 1997] could not account for the persistence of overpressures at the Red Lake bog over the 5 -year monitoring period nor the high frequency and amplitude of the surface deformations.

[22] The amount of gas lost during each of these three degassing events was estimated from the observed changes in pressure, volume, temperature, and other data using the ideal gas law and Henry's Law [cf. Fechner-Levy and Hemond, 1996]. The GPS-measured decreases in peat elevation were related to changes in the peat volume equivalent to the loss of 90,97 , and $120 \mathrm{~L} \mathrm{~m}^{-2}$ of gas at $2 \mathrm{~m}$ depth (Table 1). The mean value for dissolved methane that we measured in the pore waters at $2 \mathrm{~m}$ depth was $1.4 \mathrm{mM}$ during this period [Chasar et al., 2000a, 2000b], whereas the peat temperature at this depth was $5.0^{\circ} \mathrm{C}$ and the absolute pore pressure was 1.17 atm. A conservative estimate of the methane fraction for the gas is $54 \%$, based on field measurements and the literature [e.g., Swain et al., 1977; Swain, 1986; Chanton and Martens, 1988]. The volume of methane lost is then 57,61 , and $76 \mathrm{~L} \mathrm{~m}^{-2}$ on the basis of the ideal gas law and Henry's law. The very rapid rate of gas transport from $2 \mathrm{~m}$ depth precludes the possibility of significant methane oxidation in the aerobic zone. These three venting episodes alone are therefore equivalent to a flux of $136 \mathrm{~g} \mathrm{CH}_{4} \mathrm{~m}^{-2}$.

\section{Discussion}

\subsection{Surface Deformations}

[23] Natural peat deposits largely consist of water and therefore deform elastically in response to both shear and normal stresses. Weber [1902, pp. 107-110], translated by Couwenberg and Joosten [2002], called such deformations "Mooratmung," which he assumed were produced by changes in water storage or freeze-thaw cycles. He carefully distinguished between apparent surface oscillations related to optical illusions and actual surface displacements of $1-$ $3 \mathrm{~cm}$ that were measured with respect to a fixed surveying datum. Topographic oscillations were subsequently measured on a wide range of peatlands with standard surveying equipment or custom leveling meters [e.g., Ingram, 1983; Roulet, 1991; Quinton and Roulet, 1998; Price and Schlotzhauer, 1999.]. These measurements confirmed that the peat surface rises after each rainfall and sinks during droughts, but irreversible subsidence follows artificial drainage [Hobbs, 1986]. However, Almendinger et al. [1986] measured topographic oscillations in excess of $10 \mathrm{~cm}$ on the 


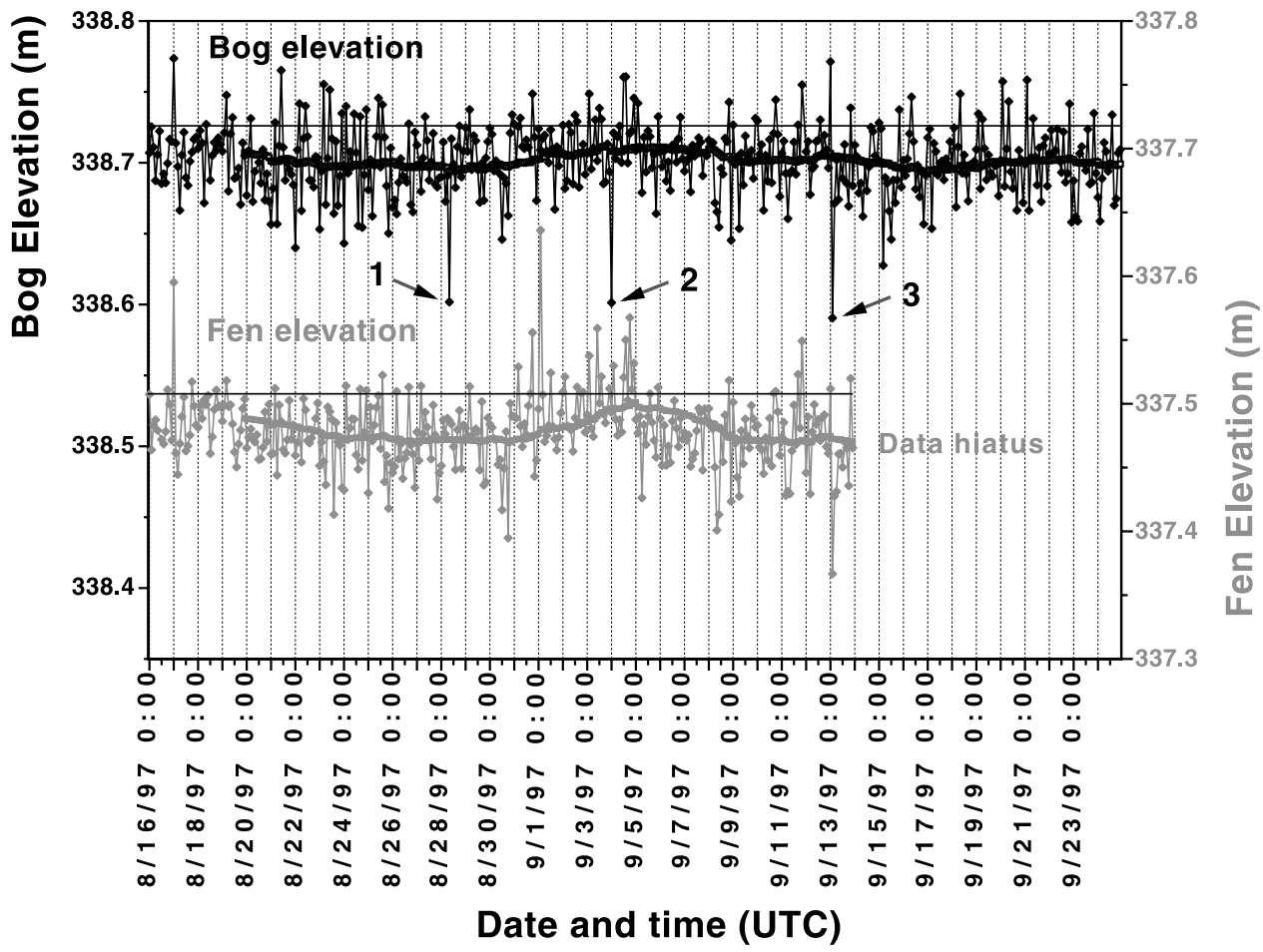

Figure 5. Surface elevations of the Red Lake bog and fen sites during a late-summer drought. Each symbol indicates the solution to a 20-min GPS-survey recorded every 2 hours. The 4-day (48 interval) moving average is indicated by the heavier line. The horizontal line marks the initial GPS elevation. Notice the three extreme low elevations at the bog site marked by arrows. See color version of this figure at back of this issue.

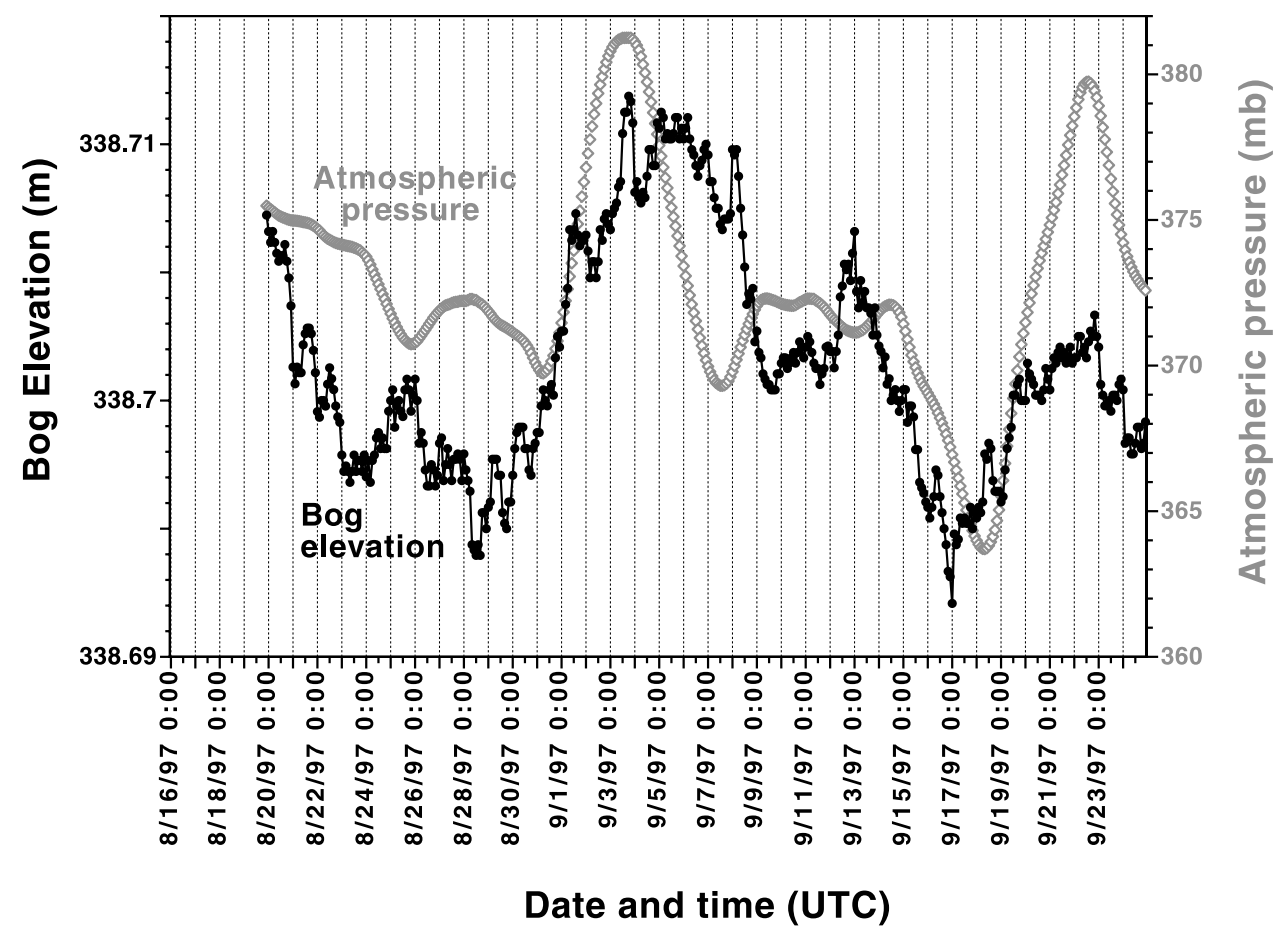

Figure 6. Four-day moving averages for atmospheric pressure and peat surface elevations at the bog site. Notice the greatly expanded scale for bog elevation and the narrow range of values $(<2 \mathrm{~cm})$. See color version of this figure at back of this issue. 

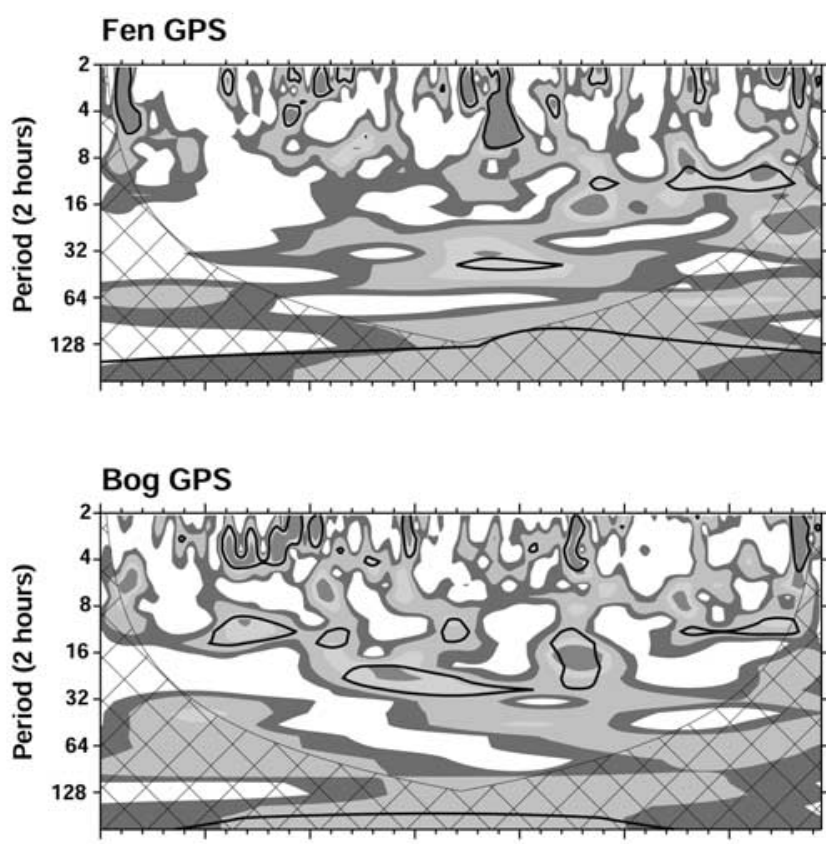

Bog Pore Pressure (2m depth)

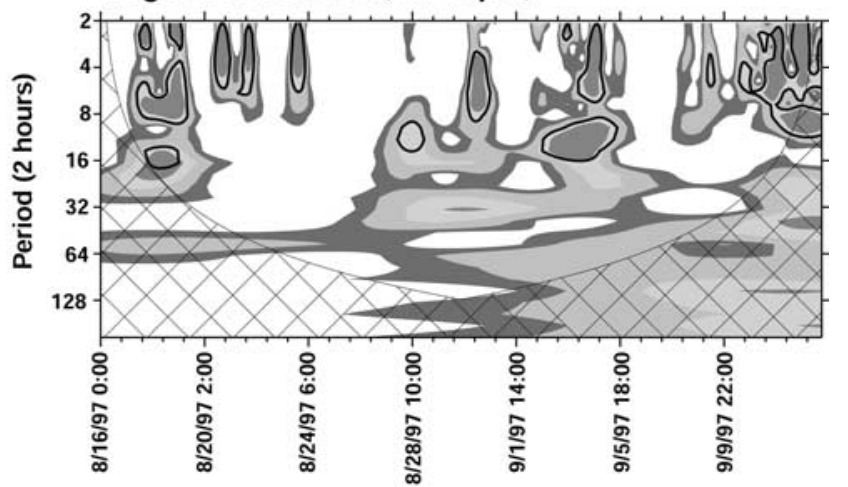

Date and Time (UTC)

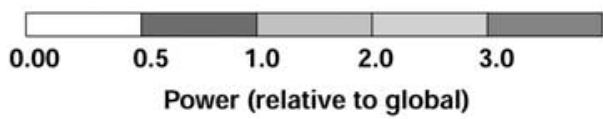

Figure 7. Wavelet power spectra for the late-summer GPS and bog-pore pressure data. The spectra show short, irregularly occurring cycles that are generally out of phase at the bog and fen sites. The contour lines indicate the $10 \%$ significance level for the red-noise band-pass filter, whereas the hatched pattern indicates the cone of influence where edge effects become important. See color version of this figure at back of this issue.

Lost River bog in northern Minnesota that were associated with climate-driven reversals in the hydraulic gradient [Siegel and Glaser, 1987; Siegel et al., 1995]. They therefore interpreted these deformations as the result of changes in pore pressure and effective stress in the deeper peat strata.

[24] The GPS stations at the Red Lake bog detected significant surface deformations with differing frequency and amplitude. A 4-day running average of the vertical oscillations indicated a gradual rise and fall of the peat surface in response to changes in water table elevations and precipitation during the early summer of 1997 . This elevational trend never exceeded $5 \mathrm{~cm}$ during the period of hourly surveys from June to mid August, and the amplitude of the trend was always greater at the fen site, reflecting the effect of runoff draining from the bog crest and collecting downslope within the internal water tracks. However, the bog and fen sites also gradually rose and fell during a period of continually falling water table levels in late summer. At this time the 4-day moving average for peat elevations closely followed that of atmospheric pressure suggesting that these longer-term oscillations in peat surface are not solely related to changes in water storage.

[25] The GPS stations also recorded higher-amplitude deformations in both the vertical and horizontal planes that exceeded $20 \mathrm{~cm}$ in 4 to 12 hours, depending on the survey interval. These higher-amplitude changes could not have been caused by changes in water storage because (1) they were most common during the early and late summer droughts, when precipitation was minimal, (2) they occurred during time intervals that were too short for large transfers of water to or from the peat mass, (3) individual rainfall events never exceeded $2.6 \mathrm{~cm}$ during the entire summer of 1997, and (4) the periodicity of the larger vertical oscillations often differed between the bog and fen sites (Figure 3, 5, and 7). It is also unlikely that these surface deformations were triggered by winds that rock the trees at the bog and fen site. The capacity of this rocking motion to create wavelike currents in the deeper pore fluids is offset by the low hydraulic conductivity of the deeper peat [Chason and Siegel, 1986] and the occurrence of many of these surface displacements at night when the air was consistently still. Moreover, the orientation of these horizontal displacements was not consistent with the prevailing southwesterly wind direction.

[26] Finally, it is unlikely that the largest topographic oscillations at the bog and fen sites were artifacts produced by an instability of the Hatch GPS antenna on mineral soil. The 24-hour surveys between the Hatch site and the local geodetic monument were within the expected $\pm 2 \mathrm{~cm}$ accuracy for surveys with Trimble 4000 GPS units, with the exception of a single 20-min solution, which was $2.9 \mathrm{~cm}$ from the mean. In contrast, the largest net changes in surface elevation at the bog and fen site exceeded $10 \mathrm{~cm}$ for both the 1-hour and 20-min surveys. Moreover, these large oscillations often occurred asynchronously at both sites, whereas any bias associated with the Hatch GPS antenna or tropospheric effects would produce smaller synchronous errors at both peatland sites.

[27] The only possible mechanism that could produce such large deformations in a semi-elastic peat mass is the accumulation and episodic release of biogenic gas bubbles within the saturated layers of peat. This explanation is supported by the nearly synchronous timing of the largest topographic oscillations and the depressuring cycles monitored at $2 \mathrm{~m}$ depth at the bog site (Figures 5, 7, 8, and 10). It is also supported by independent methods that estimate changes in bubble volume within the Red Lake bog based 


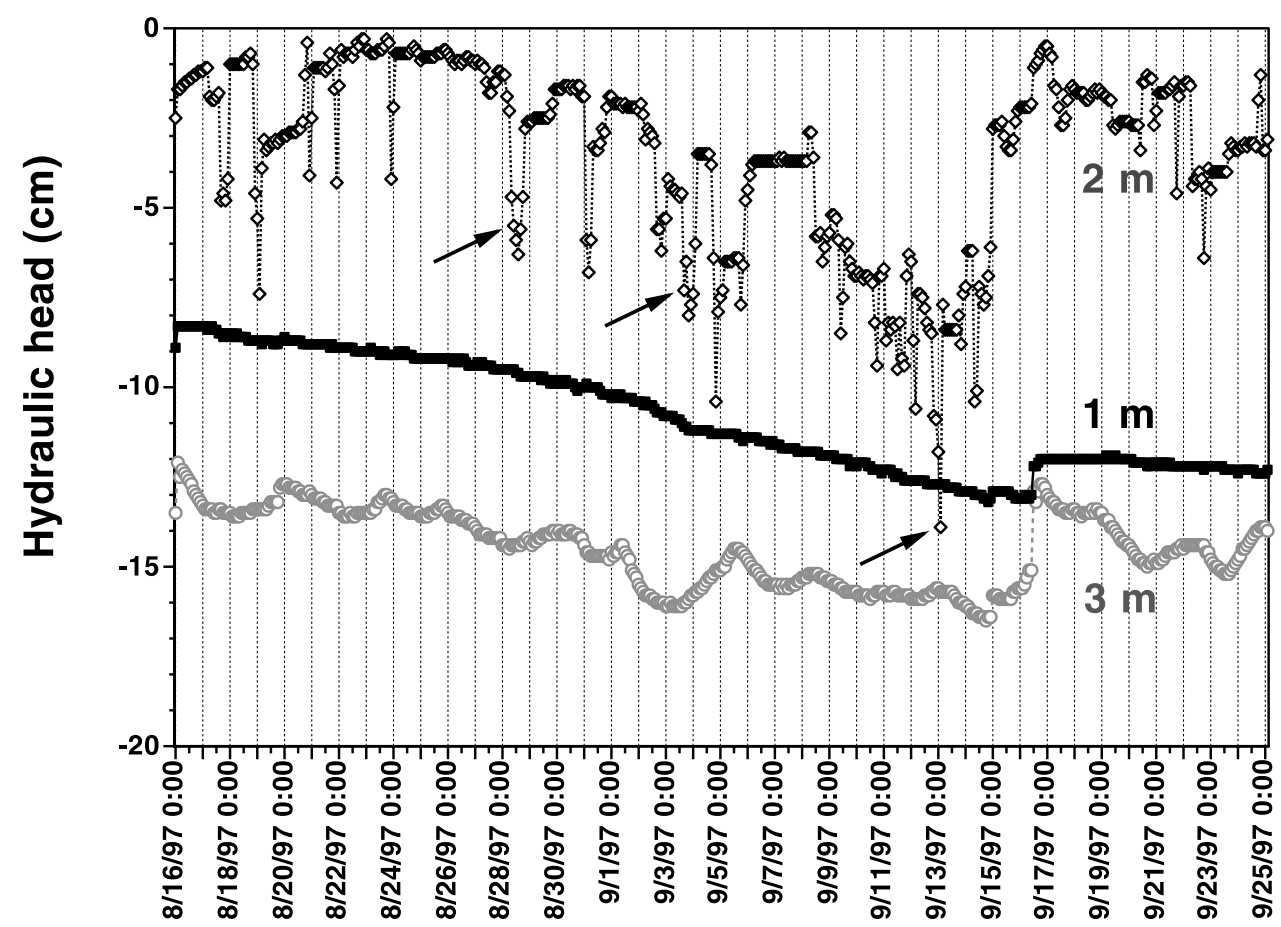

\section{Date and time (UTC)}

Figure 8. Hydraulic head (centimeters of head relative to the peat surface) collected every 2 hours at the bog site during a late summer drought. The arrows correspond to the timing of the three lowest GPS elevations. Notice the overpressure and short depressuring cycles at $2 \mathrm{~m}$ depth. Hydraulic head rose at all depths after a significant rainfall on September 16. See color version of this figure at back of this issue.

on hydrogeologic approaches [Rosenberry et al., 2003] or magnetic resonance imaging of gas-filled voids within peat cores [Glaser et al., 1998].

\subsection{Seals, Overpressures, and Ebullition Fluxes}

[28] The abnormal pressures in the Red Lake bog are analogous to conditions found in deep sedimentary basins with overpressured compartments. A sedimentary stratum is considered to be overpressured if its pore pressures exceed lithostatic pressure [Hunt, 1996; Ingebritsen and Sanford, 1998], which in shallow peat deposits is roughly equivalent to hydrostatic pressure. Overpressures develop where (1) an impermeable seal obstructs the movement of pore fluids and (2) the vertical pressure gradient is altered by some process such as the local production of hydrocarbons. Petroleum or gas production will raise the pressure within a closed compartment until the seal ruptures releasing overpressured fluids into the surrounding strata. Episodic breakout and resealing cycles occur if the seal closes after discharging fluids produce lower pore pressures in the fractures [Cartwright, 1994; Roberts and Nunn, 1995].

[29] A similar mechanism seems to be responsible for the short depressuring cycles that occurred at $2 \mathrm{~m}$ depth in the Red Lake bog during the late summer drought. A transient semi-confining layer must have been present in the deeper peat to permit the formation of overpressures at $2 \mathrm{~m}$ depth and the inverse response of hydraulic head at $3 \mathrm{~m}$ depth to barometric pressure [Freeze and Cherry, 1979; Rosenberry et al., 2003]. The depressuring cycles at $2 \mathrm{~m}$ depth, moreover, seem analogous to the breakout and resealing episodes reported for deep petroleum and gas reservoirs. Experiments with peat cores indicate that gas bubbles may occlude peat pores and decrease the hydraulic conductivity in the catotelm [Reynolds et al., 1992; Beckwith and Baird, 2001]. Romanowicz et al. [1995] therefore hypothesized that biogenic gas bubbles occlude the pores in the deeper peat strata in the GLAP, producing transient confining layers that episodically rupture and release large volumes of methane to the atmosphere. This hypothesis explained the dramatic decline in dissolved methane concentrations within the deeper peat of bog and fens after the termination of a 3-year drought.

[30] Biogenic gas bubbles rising from the deeper peat are apparently trapped within elastic layers of peat interbedded between dense horizontal bands of relatively inelastic woody peat at 1.5 to $3 \mathrm{~m}$ depth under the bog site (Figure 2). The more rigid networks of woody rootlets, branches, and stems oriented along horizontal bedding planes function as reinforcing trusses that resist deformation [Hobbs, 1996; Landva and Pheeney, 1980] from bubbles rising to the surface according to their buoyancy. Bubbles tend to accumulate in this zone and raise pore pressures until the transient semi-confining layer in the more competent peat ruptures to release a multiphase plume with free- 


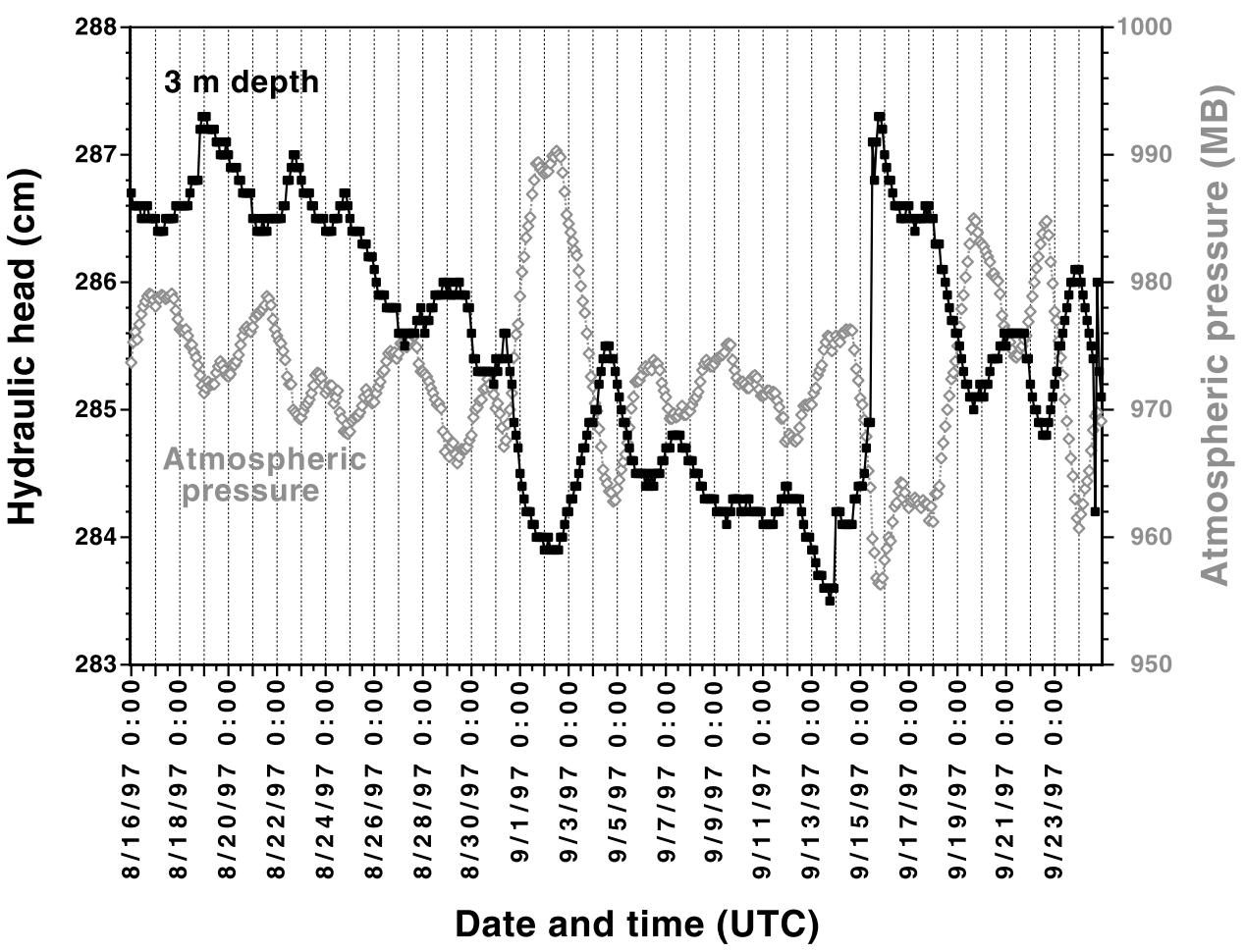

Figure 9. Inverse relationship between atmospheric pressure and hydraulic head at $3 \mathrm{~m}$ depth under the bog site. This relationship is typical of piezometers installed in confined aquifers. See color version of this figure at back of this issue.

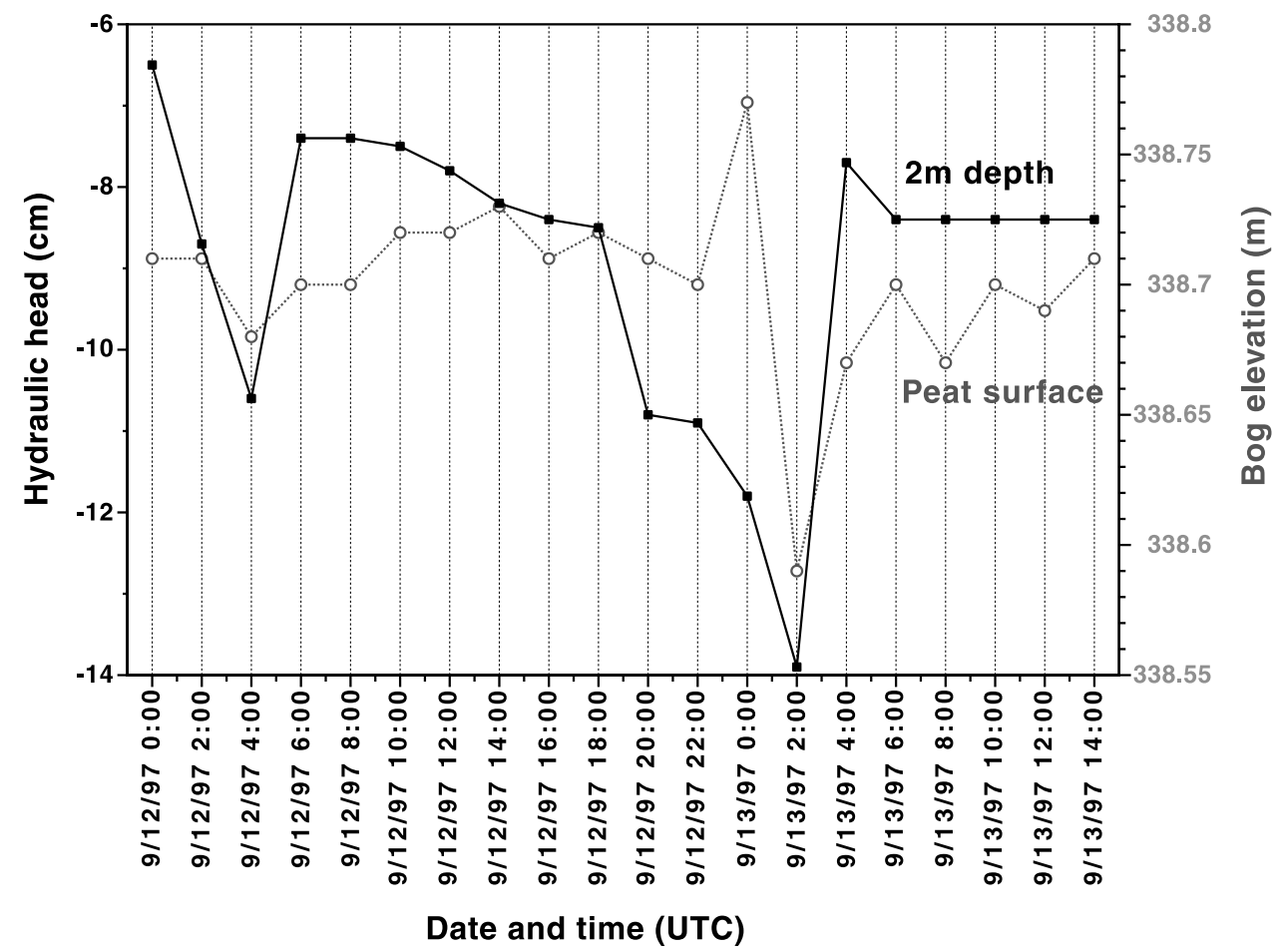

Figure 10. Synchronous changes in land-surface elevation and depressuring cycles at $2 \mathrm{~m}$ depth at the bog site. The large oscillations on September 13 were produced by the rise and escape of a bubble mass from the deeper peat followed by a rebound of the peat surface as pore waters moved laterally to fill the voids. See color version of this figure at back of this issue. 
Table 1. Ebullition Flux Calculations for the Three Largest Oscillations in Peat-Surface Elevation

\begin{tabular}{|c|c|c|c|}
\hline Calculation & August 28, 1997 & September 3, 1997 & September 12, 1997 \\
\hline GPS elevation prior to subsidence, $\mathrm{m}$ & 338.71 & 338.69 & 338.72 \\
\hline Lowest GPS elevation, $\mathrm{m}$ & 338.60 & 338.60 & 338.59 \\
\hline Mean of 3 previous elevations, $\mathrm{m}$ & 338.69 & 338.70 & 338.71 \\
\hline Elevation drop, $\mathrm{cm}$ & 9.00 & 9.67 & 12.00 \\
\hline Volume of gas lost $\left(\mathrm{L} \mathrm{m}^{-2}\right)$ at $2 \mathrm{~m}$ depth & 90 & 97 & 120 \\
\hline Methane concentration at $2 \mathrm{~m}, \mathrm{mM}$ (mean of five surrounding values) & 1.4 & 1.4 & 1.4 \\
\hline Temperature, ${ }^{\circ} \mathrm{C}$ & 5.0 & 5.0 & 5.0 \\
\hline Total pressure, atm & 1.17 & 1.17 & 1.17 \\
\hline Percent $\mathrm{CH}_{4}$ in bubble gas & 54 & 54 & 54 \\
\hline Volume (L) of methane lost per $\mathrm{m}^{2}$ at standard temperature and pressure & 61 & 65 & 81 \\
\hline Grams of $\mathrm{CH}_{4}$ lost $\mathrm{m}^{-2}$ per event & 40 & 43 & 53 \\
\hline Sum of these three events $\left(\mathrm{gm}\right.$ of $\mathrm{CH}_{4}$ lost $\left.\mathrm{m}^{-2}\right)$ & 136 & & \\
\hline
\end{tabular}

phase gas to the peat surface. Empirical observations and model simulations indicate that the fracture threshold for these confining layers in petroleum and gas reservoirs is equivalent to 0.6 times lithostatic pressure [Bredehoeft et al., 1976; Roberts and Nunn, 1995].

[31] At Red Lake the continual drop in the water table during a drought combined with sharp declines in atmospheric pressure triggered waves of depressuring events as lithostatic pressure approached this threshold (Figures 8, 10, and 11). This hypothesis is further supported by the sharp rise in overpressure at the end of the drought, when the water table rose after a significant rainfall on September 16 (Figure 8). Once the confining layer re-stabilized at higher pressure, the depressuring events became infrequent. Deep degassing may also be temporarily suppressed by a steep rise in atmospheric pressure even during periods of declin- ing water levels, such as the interval between August 31 and September 5, when an increase in gas volume apparently produced a $2-3 \mathrm{~cm}$ bulge in the peat surface at the bog and fen sites (Figure 6).

[32] A similar combination of environmental factors is probably responsible for the large surface deformations measured at the fen site. The fen GPS station was installed on a small circular tree island underlain by $3 \mathrm{~m}$ of woody peat. Biogenic gas bubbles are apparently trapped within elastic compartments interbedded between competent wood layers that more effectively resist elastic deformation. The GPS station therefore recorded large vertical and horizontal displacements on the surface of this small bog island rather than that of the adjacent sedge fen where the instrumented piezometers were installed. The head gradients in this water track provided no evidence for overpressuring or depressur-

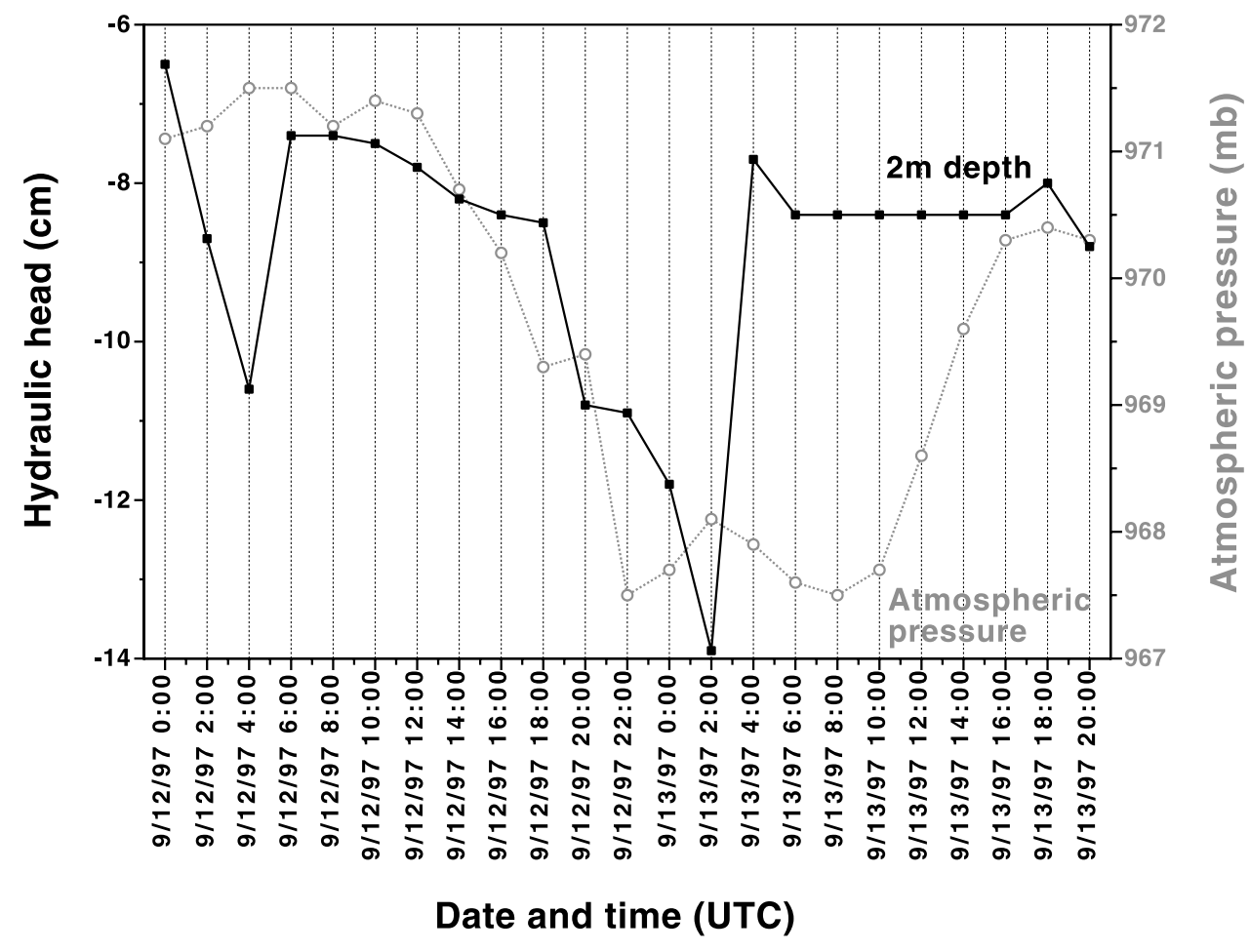

Figure 11. Synchronous changes in atmospheric pressure and depressuring cycles at $2 \mathrm{~m}$ depth at the bog site. The time interval is the same as that in Figure 10. See color version of this figure at back of this issue. 


\section{EBULLITION FLUXES $\left(\mathrm{g} \mathrm{CH}_{4} \mathrm{~m}^{-2}\right)$}

FLUXES

$\left(m g m^{-2} d^{-1}\right)$

\section{SUBSTRATES \\ ( yr B.P.)}

\section{(mg CH $\mathrm{L}^{-1} \mathrm{yr}^{-1}$ )}

35

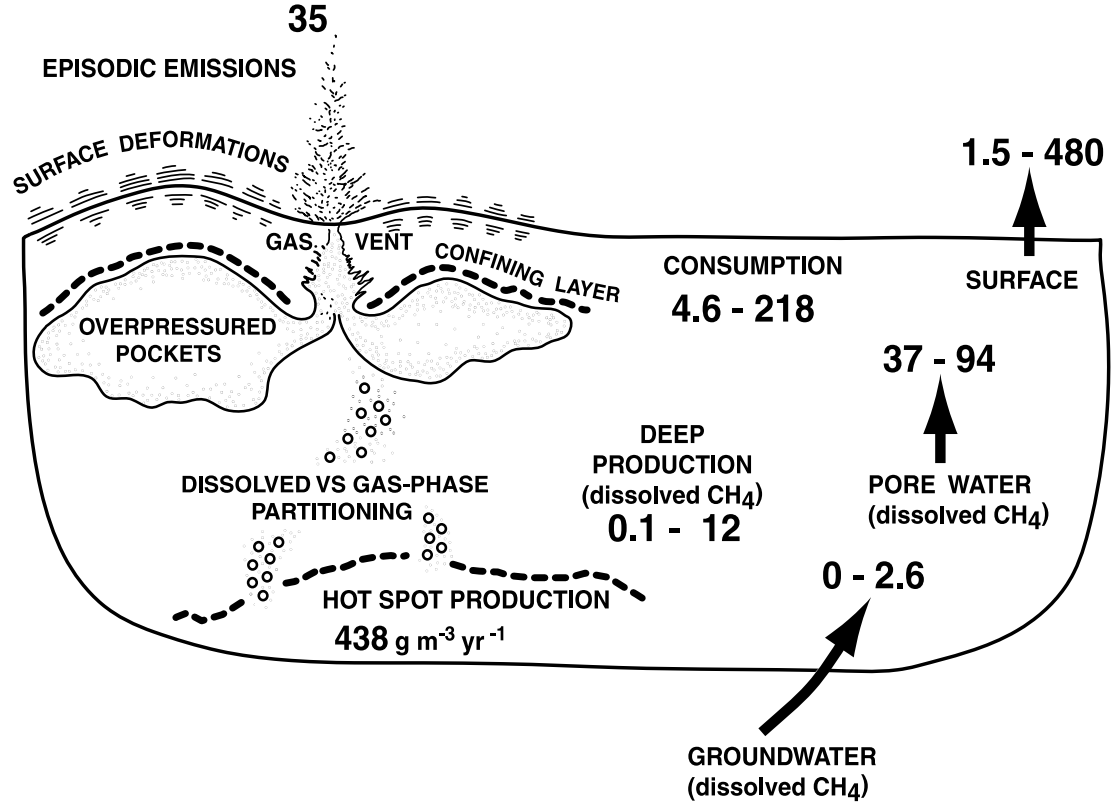

MODERN (<1)

HOLOCENE $(<6 \mathrm{~K})$

Figure 12. Methane dynamics in the Glacial Lake Agassiz peatlands. The sources for the values are (1) Chanton et al. [1995], (2) Chasar [2002], (3) Chasar et al. [2000a], (4) Chasar et al. [2000b], (5) Crill et al. [1988], (6) Crill et al. [1992], (7) P. H. Glaser et al. (this paper), (8) Romanowicz et al. [1993], (9) Romanowicz et al. [1995], (10) Rosenberry et al. [2003], (11) Siegel et al. [2001].

ing cycles because its peat profile is largely composed of sedge peat, which apparently offers less resistance to buoyantly rising gas bubbles. It is assumed that the more elastic properties of the saturated sedge peats in the water track are probably also responsible for the greater horizontal displacements observed at the fen GPS station relative to those at the bog site. The orientation of these horizontal displacements at both the bog and fen sites is probably aligned to the focal point for an ebullition eruption.

\subsection{Methane Fluxes in the Glacial Lake Agassiz Peatlands}

[33] The late-summer drought triggered 18 depressuring cycles including three large ebullition events that released over $130 \mathrm{~g} \mathrm{CH}_{4} \mathrm{~m}^{-2}$. These large emissions are an order of magnitude higher than the average annual emissions of methane of $13 \mathrm{~g} \mathrm{~m}^{-2} \mathrm{yr}^{-1}$ estimated by seasonal sampling with chambers at the Red Lake bog site in 1997 [Chasar, 2002]. These ebullition fluxes also exceed the average methane flux estimated by chambers across the GLAP during short field campaigns, although the range of values also includes several very large fluxes [Crill et al., 1988, 1992; Chanton et al., 1995]. Isotopic studies in the GLAP, however, indicate that methane produced in the deeper peat or underlying groundwater is not captured by surface chambers (Figure 12). Methane from chambers has a modern radiocarbon signature that indicates production in shallow peat strata from recently deposited plant remains or root exudates [Chanton et al., 1995; Chasar et al., 2000a, 2000b; Chasar, 2002]. Methane dissolved in the deeper pore waters, in contrast, has a significantly lower radiocarbon activity, particularly in bogs. The deeper methane is consistently 1000-2000 years younger than the age of the adjacent peat at any sampling depth, indicating production from some mixture of old and young carbon substrates. Apparently methanogenesis in the deeper peat is stimulated by the downward transport of labile organic compounds that are released from plant roots. This effect has also been reported in other peatlands [Charman et al., 1994]. Methane older than 40,000 years was also found in the deep groundwaters at the southern periphery of the peatlands [Chanton et al., 1995].

[34] The downward transport of labile carbon substrates apparently sustains the high rates of methane production in the deeper peat strata. Existing data on methane production and transport in the deeper pore waters is largely based on the dissolved phases of this greenhouse gas (Figure 12). Romanowicz et al. [1995] calculated diffusive flux rates of 37-94 $\mathrm{mg} \mathrm{m}^{-2} \mathrm{~d}^{-1}$ using dissolved methane concentration gradients within the deeper pore fluids of 30 bogs and fens within the GLAP. They then estimated production rates of $0.1-12 \mathrm{mg} \mathrm{L}^{-1} \mathrm{yr}^{-1}$ by fitting concentration data to an analytical model developed by Martens and Berner [1977]. Siegel et al. [2001], in contrast, identified much higher rates of production ( $438 \mathrm{~g} \mathrm{CH}_{4} \mathrm{~m}^{-3} \mathrm{yr}^{-1}$ ) in local hot spots, such as the overpressured compartment of the Red Lake bog, by using an isotopic mass balance based on the capacity for methanogenesis to enrich the surrounding pore waters in deuterium (Figure 2). Although rates of methane oxidation are high in the acrotelm [Chasar, 2002], a significant 
fraction of this deeper production appears to be unaccounted for by the chamber fluxes.

[35] Deep ebullition fluxes may therefore be a large component of the total methane emissions from the Glacial Lake Agassiz peatlands (Figure 12). These large ebullition events seem to be triggered by either climatic factors that lower the fracture threshold of the confining layer (e.g., drop in water table or atmospheric pressure) or the accumulation of biogenic gas that raises the pore pressures within a semi-confined gas compartment. The episodic nature of these ebullition events, which are discontinuous in time and space, makes it difficult to estimate regional ebullition fluxes across the $1236 \mathrm{~km}^{2}$ of bogs and $4718 \mathrm{~km}^{2}$ of fens within the GLAP study area.

[36] Romanowicz et al. [1995] proposed deep ebullition to explain the dramatic change in concentration of methane dissolved in the deeper pore fluids across the GLAP during a multiyear drought cycle. Large concentrations of dissolved methane and inorganic carbon (DIC) were found in the deeper pore waters of 32 bogs and fens throughout the GLAP at the height of a 3-year drought in 1990 [Romanowicz et al., 1993, 1995; Glaser et al., 1997]. The DIC values, moreover, plotted above the DIC versus $\mathrm{Ca}$ mixing line indicating the addition of DIC from an internal source, which is most likely $\mathrm{CO}_{2}$ produced by fermentation bacteria and methanogens [Glaser et al., 1997]. Zones of overpressure were observed on many of the bog sites at this time, and boreholes drilled into the deeper peat often bubbled violently after the sampler was removed [Siegel et al., 2001]. However, the following year, concentrations of methane and DIC dropped two- to three-fold in concentration in the deep pore waters of the same sites following only a month of normal precipitation (Figure 2). The DIC values also plotted along the DIC versus $\mathrm{Ca}$ mixing line, indicating that most of the DIC was bicarbonate derived from either groundwater or the atmosphere [Glaser et al., 1997]. Rosenberry et al. [2003] presented independent evidence for large ebullition fluxes from the Red Lake bog site that conformed with those calculated here with the GPS and pore pressure data.

\section{Conclusions}

[37] Several lines of evidence suggest that deep ebullition fluxes are an important component of methane emissions in northern peatlands. The once widespread sightings of "will 'o the wisp" (c.f. ignis fatuus) on northern European peatlands were probably the result of methane ebullitions ignited by lanterns or other ignition sources formerly used for nighttime illumination [Simpson and Weiner, 1989]. Bubbling eruptions of gases were also reported in flooded peat cuttings or boreholes [Weber, 1902, p. 245] or inferred from observations of mud volcanoes or fissures on the surface of bogs [Thomson, 1924; Gams and Ruoff, 1929; Aario, 1932].

[38] More recently, localized pockets of gas have been tapped with gas sampling probes in several discontinuous peatlands in North America [Dinel et al., 1988; Brown et al., 1989; Brown, 1998], although these gas pockets appear to be rarer in the catotelm of bogs in the British Isles [Clymo and Pearce, 1995; R. S. Clymo, Gas bubbles in peat, unpub- lished manuscript, 2001]. Deep degassing may therefore provide a source for the episodic ebullition fluxes that are occasionally captured by chambers or eddy-covariance studies during spring thaw [e.g., Christensen, 1993; J. P. Chanton and G. Whiting, unpublished data, 2000] or drought cycles [Moore et al., 1990; Moore and Roulet, 1993; Mathews, 2000]. Episodic ebullition of methane has also been proposed as the mechanism for the steep decline in methane dissolved in pore fluids from peatlands in North America following droughts [Moore et al., 1990; Romanowicz et al., 1995]. However, such localized and episodic events probably require measurements over wider spatial and temporal scales than is possible in most field investigations.

[39] The Red Lake study indicates that ebullition fluxes from the catotelm may be a significant and potentially large source for methane emissions from northern peatlands. This assumption is partly based on the broad similarity of peatlandform patterns in large peat basins particularly with respect to bog complexes with internal water tracks [Glaser and Janssens, 1986; Vitt et al., 1994]. The peat stratigraphy of these landforms often contain dense wood layers interbedded with more elastic peat [Glaser and Janssens, 1986; Janssens et al., 1992; Vitt et al., 1994] forming efficient traps for biogenic gas bubbles. Anaerobic metabolism could still produce significant quantities of free-phase gas in the deeper peat even without the additional stimulation provided by root exudates because of the long residence times of carbon in the catotelm. Episodic ebullition events could then be triggered by either climatic mechanisms (e.g., fall in the water table or atmospheric pressure) or internal processes (e.g., continual accumulation of gas bubbles).

[40] Acknowledgments. We thank Barbara Perin and Wayne Shiver from UNAVCO for providing GPS technical support and equipment for the project, Charles Meertens for verifying select 1-hour GPS surveys using Bernice GPS software, Lee Andrew for piloting the helicopter, and the Minnesota Department of Natural Resources for providing the use of its building in Waskish, Minnesota, as a field station. Nigel Roulet and an anonymous reviewer provided insightful comments for improving the manuscript. This research was funded by the U.S. National Science Foundation.

\section{References}

Aario, L. (1932), Pflanzentopographische un paläogeographische mooruntersuchungen in N-Satakunta, Fennia, 55, 1-179.

Almendinger, J. C., J. E. Almendinger, and P. H. Glaser (1986), Topographic fluctuations across a spring-fen and raised bog in the Lost River peatland, northern Minnesota, J. Ecol., 74, 393-401.

Baker, D. G., D. A. Haines, and J. H. Stubb (1967), Climate of Minnesota: V. Precipitation facts normals, and extremes, Univ. Minn. Agric. Exp. Stat. Tech. Bull., 254, 1-43.

Baker, D. G., W. W. Nelson, and E. L. Kuehnast (1979), Climate of Minnesota: XII. The hydrologic cycle and soil water, Univ. Minn. Agric. Exp. Stat. Tech. Bull., 322, 1-23.

Baker, D. G., E. L. Kuehnast, and J. A. Zandlo (1985), Climate of Minnesota: XV. Normal temperatures $(1951-1980)$ and their application, Univ. Minn. Agric. Exp. Stat. Tech. Bull., AD-SB-2777.

Beckwith, C. W., and A. J. Baird (2001), Effect of biogenic gas bubbles on water flow through poorly decomposed blanket peat, Water Resour. Res., $37,551-558$.

Bredehoeft, J. D., R. G. Wolff, W. S. Keys, and E. Shuter (1976), Hydraulic fracturing to determine the regional in situ stress, Piceance Basin, Colorado, Geol. Soc. Am. Bull., 87, 250-258.

Bridgham, S. D., K. Updegraff, and J. Pastor (1998), Carbon, nitrogen, and phosphorus mineralization in northern wetlands, Ecology, 79, 15451561.

Brown, A., S. P. Mathur, and D. J. Kushner (1989), An ombrotrophic bog as a methane reservoir, Global Biogeochem. Cycles, 3, 205-213. 
Brown, D. A. (1998), Gas production from an ombrotrophic bog: Effect of climate change on microbial ecology, Clim. Change, 40, $277-284$.

Cartwright, J. A. (1994), Episodic basin-wide fluid expulsion from geopressured shale sequences in the North Sea basin, Geology, 22, 447450

Chanton, J. P., and C. S. Martens (1988), Seasonal variations in ebullitive flux and carbon isotopic composition of methane in a tidal freshwater estuary, Global Biogeochem. Cycles, 2, 289-298.

Chanton, J. P., J. Bauer, P. H. Glaser, D. I. Siegel, C. Kelley, S. C. Tyler, E. A. Romanowicz, and A. Lazrus (1995), Radiocarbon evidence for the substrates supporting methane formation within northern Minnesota peatlands, Geochim. Cosmochim. Acta, 59, $3663-$ 3688.

Charman, D. J., R. Aravena, and B. G. Warner (1994), Carbon dynamics in a forested peatland in north-eastern Canada, J. Ecol., 82, 55-62.

Chasar, L. C. (2002), Implications of Environmental Change for Energy Flow Through Natural Systems: Wetlands and Coastal Systems, Ph.D. dissertation, 320 pp., Florida State Univ., Tallahassee, Fla.

Chasar, L. S., J. P. Chanton, P. H. Glaser, D. I. Siegel, and J. S. Rivers (2000a), Radiocarbon and stable carbon isotopic evidence for transport and transformation of dissolved organic carbon, dissolved inorganic carbon, and $\mathrm{CH}_{4}$ in a northern Minnesota peatland, Global Biogeochem. Cycles, 14, 1095-1108.

Chasar, L. S., J. P. Chanton, P. H. Glaser, and D. I. Siegel (2000b), Methane concentration and stable isotope distribution as evidence of rhizospheric processes: Comparison of a fen and bog in the Glacial Lake Agassiz peatland complex, Ann. Bot. London, 86, 655-663.

Chason, D. B., and D. I. Siegel (1986), Hydraulic conductivity and related physical properties of peat, Lost River Peatland, northern Minnesota, Soil Sci., 142, $91-99$

Christensen, T. R. (1993), Methane emissions from Arctic tundra, Biogeochemistry, 21, 117-139.

Clymo, R. S., and D. M. E. Pearce (1995), Methane and carbon dioxide production in, transport through, and efflux from a peatland, Philos. Trans. R. Soc. London, Ser. A, 350, 249-259.

Couwenberg, J., and H. Joosten (Eds.) (2002), C. A. Weber and the Raised Bog of Augstumal, IMCG, Tula, Russia.

Crill, P. M., K. B. Bartlett, R. C. Harriss, E. Gorham, E. S. Verry, D. I. Sebacher, L. Madzar, and W. Sanner (1988), Methane flux from Minnesota peatlands, Global Biogeochem. Cycles, 2(4), 371-384.

Crill, P., K. B. Bartlett, and N. T. Roulet (1992), Methane flux from boreal peatlands, Suo, 43, 173-182.

Devito, K. J., J. M. Waddington, and B. A. Branfireun (1997), Flow reversals in peatlands influenced by local groundwater systems, Hydrol. Processes, 11, 103-110

Dinel, H., S. P. Mathur, A. Brown, and M. Lévesque (1988), A field study of the effect of depth on methane production in peatland waters: Equipment and preliminary results, J. Ecol., 76, 1083-1091.

Domenico, P. A., and F. W. Schwartz (1990), Physical and Chemical Hydrogeology, John Wiley, New York.

Fechner-Levy, E. J., and H. F. Hemond (1996), Trapped methane volume and potential effects on methane ebullition in a northern peatland, Limnol. Oceanogr., 41, 1375-1383.

Freeze, R. A., and J. A. Cherry (1979), Groundwater, Prentice-Hall, Old Tappan, N. J.

Gams, H., and S. Ruoff (1929), Geschichte, Aufbau und Pflanzendecke des Zelaubruches, Monographie eines wachsenden Hochmoores in Ostpreuoen, Schrift. Physik. Ges. Konigsb., LXVI, 1-193.

Glaser, P. H. (1992), Peat landforms, in Patterned Peatlands of Northern Minnesota, edited by H. E. Wright Jr. and B. A. Coffin, pp. 3-14, Univ. Minn. Press, Minneapolis, Minn.

Glaser, P. H., and J. A. Janssens (1986), Raised bogs in eastern North America: Transitions in landforms and gross stratigraphy, Can. J. Bot., 64, 395-415.

Glaser, P. H., G. A. Wheeler, E. Gorham, and H. E. Wright Jr (1981), The patterned peatlands of the Red Lake peatland, northern Minnesota: Vegetation, water chemistry, and landforms, J. Ecol., 69, $575-599$.

Glaser, P. H., D. I. Siegel, E. A. Romanowicz, and Y. P. Shen (1997), Regional linkages between raised bogs and the climate, groundwater, and landscape features of northwestern Minnesota, J. Ecol., 85, 316.

Glaser, P. H., P. J. Morin, J. Kamp, N. Tsekos, and D. I. Siegel (1998), Measuring biogenic gas bubbles in peat cores by magnetic resonance imaging, Eos, 79(7), S48.

Gorham, E. (1991), Northern peatlands: Role in the carbon cycle and probable responses to climatic warming, Ecol. Appl., 1, 182-195.
Hobbs, N. B. (1986), Mire morphology and the properties and behaviour of some British and foreign peats, Q. J. Eng. Geol., 19, 7-80.

Hofmann-Wellenhof, B., H. Lichtenegger, and J. Collins (1997), Global Positioning System, Theory and Practice, Springer-Verlag, New York.

Hunt, J. M. (1996), Petroleum Geochemistry and Geology, 2nd ed., Freeman, San Francisco, Calif.

Ingebritsen, S. E., and W. E. Sanford (1998), Groundwater in Geologic Processes, Cambridge Univ. Press, New York.

Ingram, H. A. P. (1983), Hydrology, in Mires: Swamp, Bog, Fen, and Moor, vol. 4A, General Studies, edited by A. J. P. Gore, pp. 67-158, Elsevier Sci., New York

Janssens, J. A., B. C. S. Hansen, P. H. Glaser, and C. W. Barnosky (1992), Development of a raised-bog complex in northern Minnesota, in Patterned Peatlands of Northern Minnesota, edited by H. E. Wright Jr. and B. A. Coffin, pp. 189-221, Univ. of Minn. Press, Minneapolis, Minn.

Landva, A. O., and P. E. Pheeney (1980), Peat fabric and structure, Can. Geotech. J., 17, 416-435.

Martens, C. S., and R. A. Berner (1977), Interstitial water chemistry of anoxic Long Island Sound sediments: 1. Dissolved gases, Limnol. Oceanogr., 22, 10-25.

Mathews, E. (2000), Wetlands, in Atmospheric Methane: Its Role in the Global Environment, edited by M. A. K. Khalil, pp. 202-233, SpringerVerlag, New York.

Moore, T. R., and N. T. Roulet (1993), Methane flux: Water table relations in northern wetlands, Geophys. Res. Lett., 20, 587-590.

Moore, T. R., N. Roulet, and R. Knowles (1990), Spatial and temporal variations of methane flux from subarctic/northern boreal fens, Global Biogeochem. Cycles, 4, 29-46.

Price, J. S., and S. M. Schlotzhauer (1999), Importance of shrinkage and compression in determining water storage changes in peat: The case of a mined peatland, Hydrol. Processes, 13, 2591-2601.

Quinton, W. L., and N. T. Roulet (1998), Spring and summer runoff hydrology of a subarctic patterned wetland, Arct. Alp. Res., 30, $285-$ 294.

Reynolds, W. D., D. A. Brown, S. P. Mathur, and R. P. Overend (1992), Effect of in-situ gas accumulation on the hydraulic conductivity of peat, Soil Sci., 153, 397-408.

Roberts, S. J., and J. A. Nunn (1995), Episodic fluid expulsion from geopressured sediments, Mar. Petrol. Geol., 12, 195-204.

Romanowicz, E. A., D. I. Siegel, and P. H. Glaser (1993), Hydraulic reversals and episodic methane emissions during drought cycles in mires, Geology, 21, 231-234.

Romanowicz, E. A., D. I. Siegel, J. P. Chanton, and P. H. Glaser (1995), Temporal variations in dissolved methane deep in the Lake Agassiz peatlands, Minnesota (USA), Global Biogeochem. Cycles., 9, 197212

Rosenberry, D. O., P. H. Glaser, D. I. Siegel, and E. D. Weeks (2003), Use of hydraulic head to estimate volumetric gas content and ebullition flux in northern peatlands, Water Resour. Res., 39(3), 1066.

Roulet, N. T. (1991), Surface level and water table fluctuations in a subarctic fen, Arct. Alp. Res., 23, 303-310.

Siegel, D. I., and P. H. Glaser (1987), Groundwater flow in a bog-fen complex, Lost River peatland, northern Minnesota, J. Ecol., 75, $743-$ 754.

Siegel, D. I., A. S. Reeve, P. H. Glaser, and E. Romanowicz (1995), Climate-driven flushing of pore water in humified peat, Nature, 374, 531533.

Siegel, D. I., J. P. Chanton, P. H. Glaser, L. S. Chasar, and D. O. Rosenberry (2001), Estimating methane production rates in bogs and landfills by deuterium enrichment of pore-water, Global Biogeochem. Cycles, 15 , 967-975.

Simpson, J. A., and E. S. C. Weiner (Eds.) (1989), Oxford English Dictionary, 2nd ed., Oxford Univ. Press, New York.

Swain, F. M. (1986), Composition of marsh gases in the central and eastern United States, Appl. Geochem., 1, 301-305.

Swain, F. M., B. D. Johnson, and J. J. Pittman (1977), Environmental aspects of marsh gas, in Interdisciplinary Studies of Peat and Coal Origins, edited by P. H. Given and A. D. Cohen, Microfilm Publ. 7, Geol. Soc. of Am., Boulder, Colo.

Thomson, P. V. (1924), Influence of eruption of gas on the surface patterns of bogs, Bot. Arch., 8, 1-2.

Torrence, C., and G. P. Compo (1998), A practical guide of wavelet analysis, Bull Am. Meteorol. Soc., 79, 61-78.

Vitt, D. H., L. A. Halsey, and S. C. Zoltai (1994), The bog landforms of continental western Canada in relation to climate and permafrost patterns, Arct. Alp. Res., 26, 1-13. 
Waddington, J. M. (1995), Hydrological and biogeochemical controls of carbon storage and fluxes $\left(\mathrm{CO}_{2}, \mathrm{CH}_{4}\right.$, and dissolved) in a boreal peatland, Ph.D. dissertation, York Univ., North York, Ont., Canada.

Waddington, J. M., and N. T. Roulet (1997), Groundwater flow and dissolved carbon movement in a boreal peatland, J. Hydrol., 191, $122-138$.

Weber, C. A. (1902), Über die Vegetation und Entstehung des Hochmoors von Augstumal im Memeldelta mit vergleichenden Ausblicken auf andere Hochmoore der Erde, Paul Parey, Berlin.

Wieder, R. K., J. B. Yavitt, and G. E. Lang (1990), Methane production and sulfate reduction in 2 Appalachian peatlands, Biogeochemistry, 10, 81 104.

Wright, H. E., Jr. (1972), Physiography of Minnesota, in Geology of Minnesota: A Centennial Volume, edited by P. K. Sims and G. B. Morey, pp. 515-560, Minn. Geol. Surv., Minneapolis, Minn.

Yavitt, J. B., and G. E. Lang (1990), Methane production in contrasting wetland sites- Response to organic-chemical components of peat and to sulfate reduction, Geomicrobiol. J., 8, 27-46.

Yavitt, J. B., C. J. Williams, and R. K. Wieder (1997), Production of methane and carbon dioxide in peatland ecosystems across North Amer- ica: Effects of temperature, aeration and organic chemistry of peat, Geomicrobiol. J., 14, 299-316.

J. P. Chanton, Department of Oceanography, Florida State University, Tallahassee, FL 32306-4320, USA. (jchanton@mailer.fsu.edu)

L. I. Chasar, District Office, U.S. Geological Survey, Tallahassee, FL 32301, USA. (1chasar@usgs.gov)

P. H. Glaser and P. Morin, Department of Geology and Geophysics, 220D Pillsbury Hall, 310 Pillsbury Drive, SE, University of Minnesota, Minneapolis, MN 55455, USA. (glase001@tc.umn.edu; lpaul@umn.edu)

A. S. Reeve, Department of Geological Sciences, University of Maine, Orono, ME 04469, USA. (asreeve@maine.maine.edu)

D. O. Rosenberry, Water Resources Division, U.S. Geological Survey, MS 413, Building 53, Denver Federal Center, Lakewood, CO 80225, USA. (rosenber@usgs.gov)

O. Ruud, UNAVCO, 3340 Mitchell Lane, P.O. Box 3000, Boulder, CO 80301, USA. (ruud@unavco.ucar.edu)

D. I. Siegel, Department of Earth Sciences, Syracuse University, Syracuse, NY 13244, USA. (disiegel@mailbox.syr.edu) 


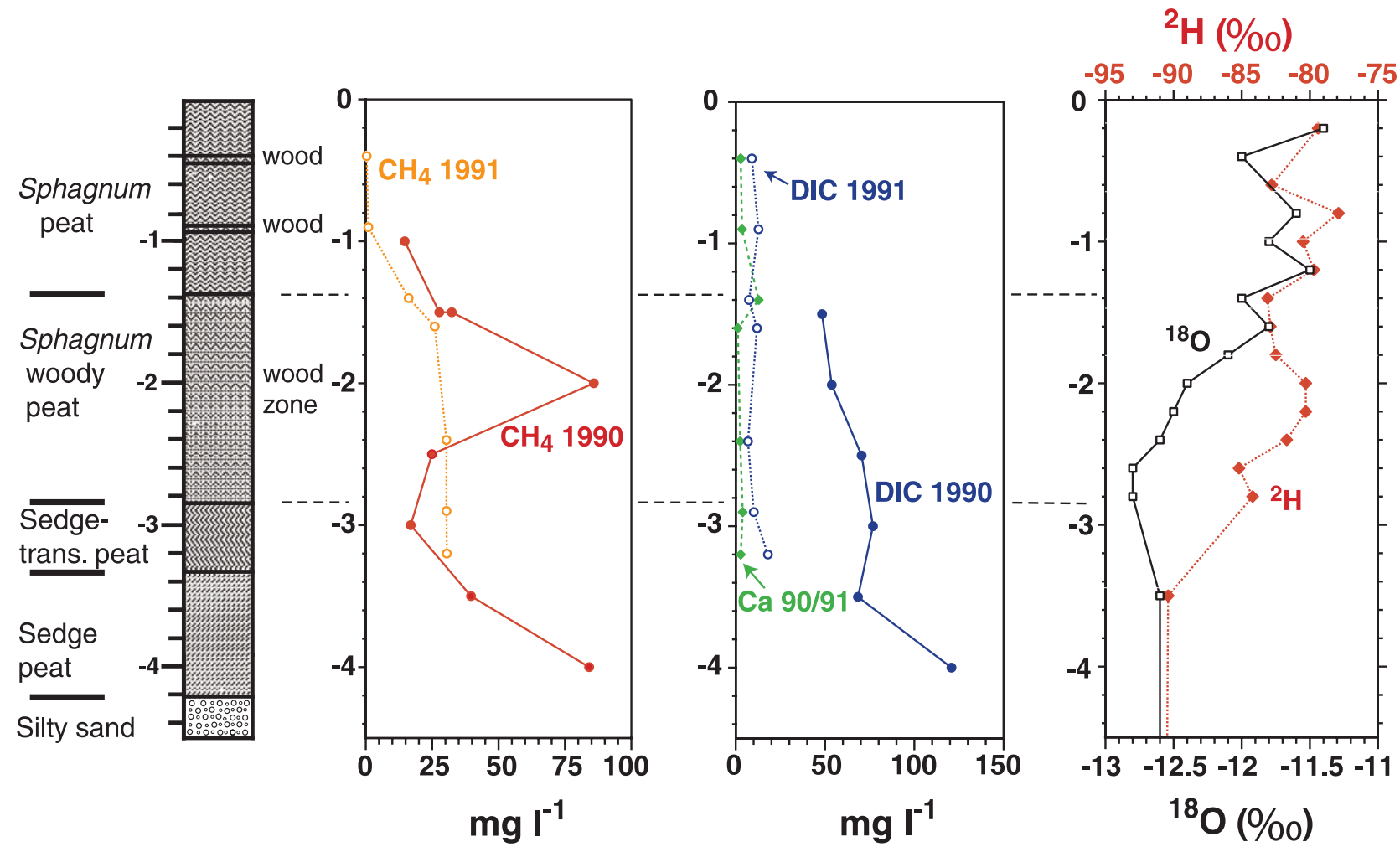

Figure 2. Peat stratigraphy at the Red Lake II bog site with respect to pore water concentration of dissolved methane, dissolved inorganic carbon (DIC), deuterium, and ${ }^{18} \mathrm{O}$. High values for methane and DIC occurred in a zone of woody Sphagnum peat below $1 \mathrm{~m}$ depth during an extreme drought in 1990 [Romanowicz et al., 1995; Glaser et al., 1997]. The deeper pore waters are also enriched in deuterium relative to ${ }^{18} \mathrm{O}$, indicating high rates of methanogenesis [Siegel et al., 2001]. All depths are presented relative to the peat surface. 


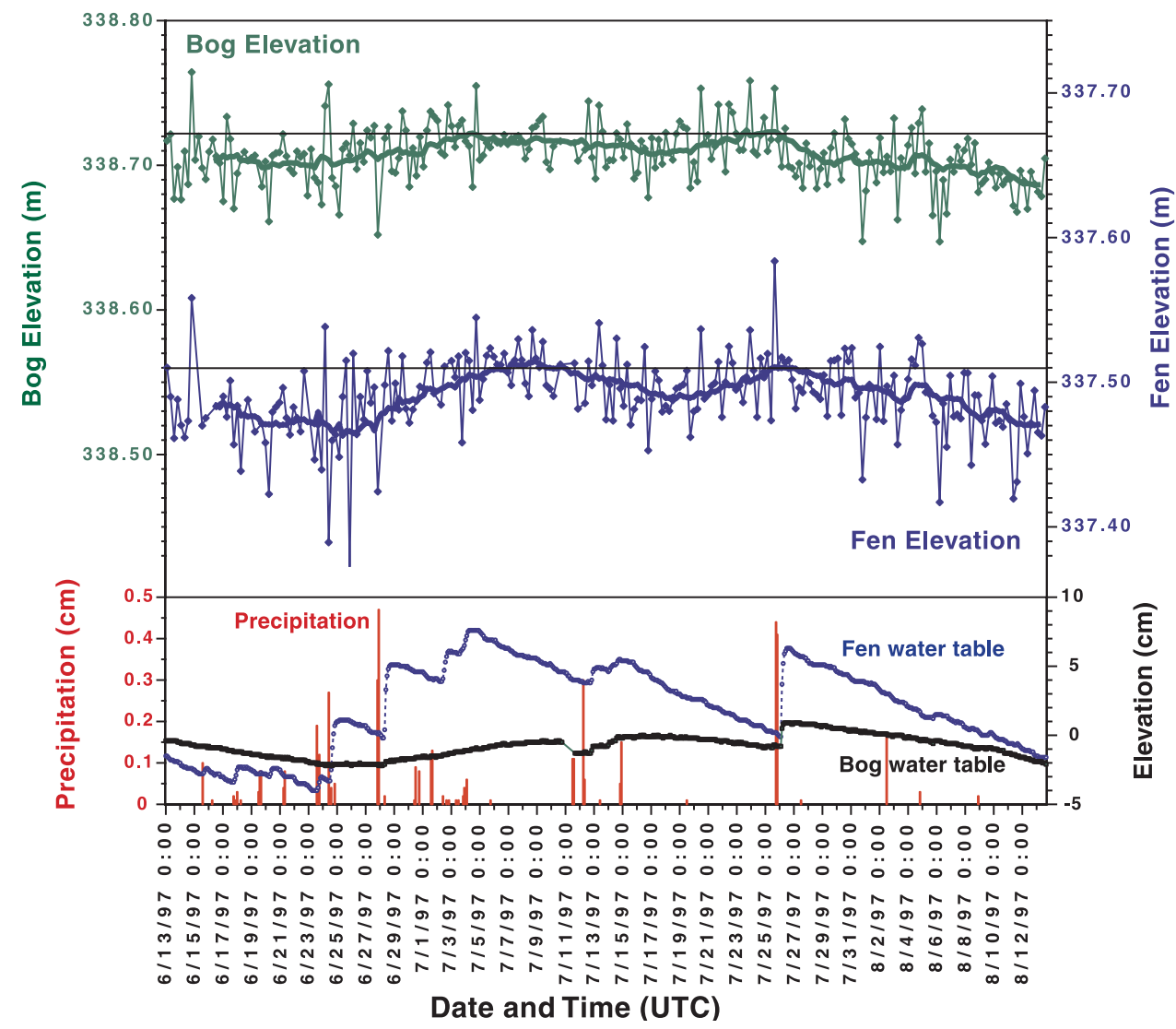

Figure 3. Surface elevations of the Red Lake bog and fen site during an early summer drought cycle. Periods with minimal precipitation and falling water tables were associated with (1) high amplitude topographic oscillations (diamonds indicate solutions to the hourly GPS surveys recorded every 6 hours) and (2) gradual decline in the average surface elevation (thick line indicates 4-day moving average). The GPS elevations are plotted relative to a horizontal line indicating the initial survey elevation. The bottom panel shows precipitation (bars) recorded at the Hatch site and water table elevations recorded at the bog and fen sites. Note the 18-hour data hiatus for the bog water table on July 9-10. 

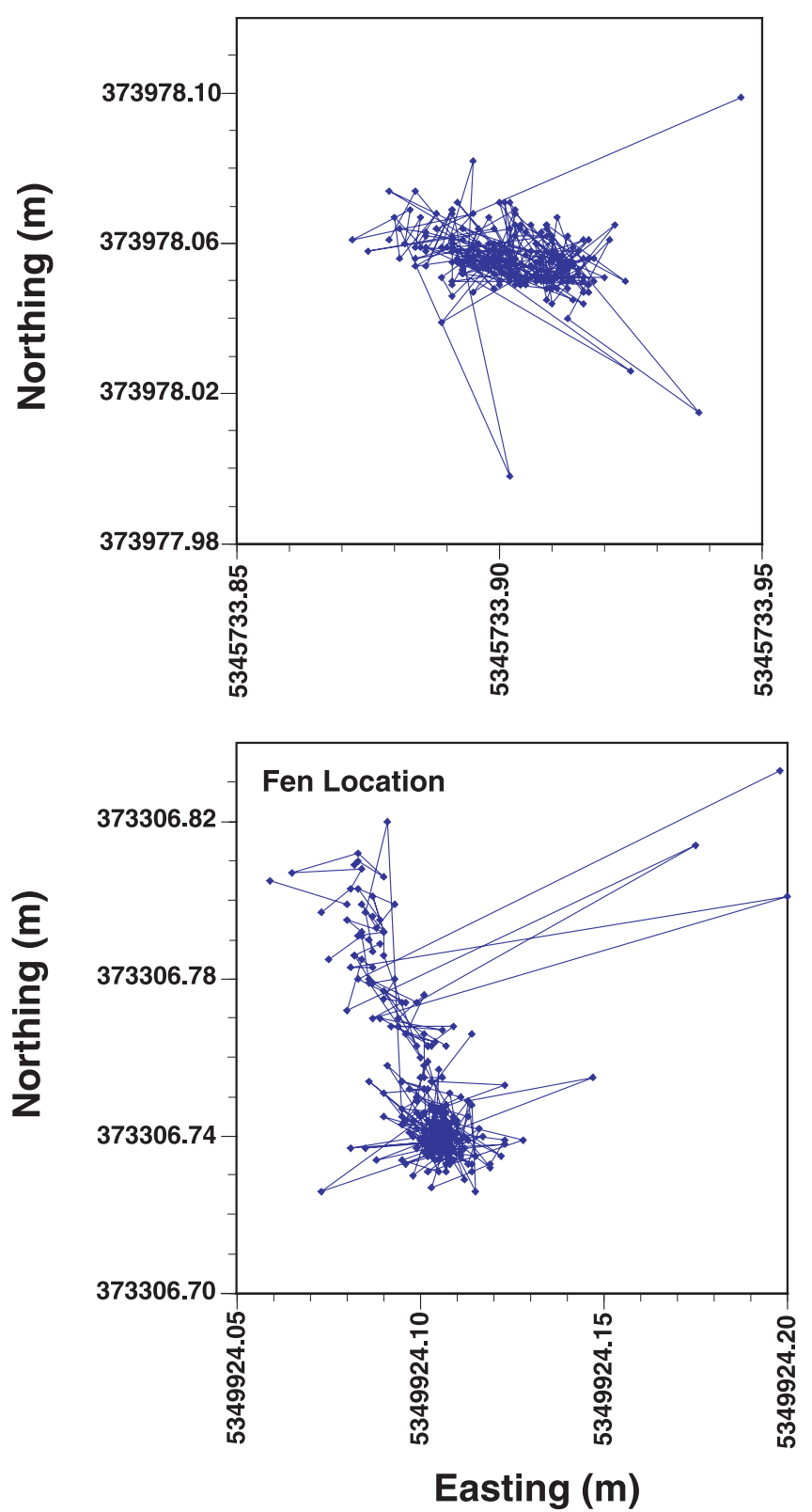

Figure 4. Horizontal surface displacements at the Red Lake bog and fen sites. Each symbol indicates the solution to an hourly GPS survey recorded every 6 hours from June 13 to August 14 . The data sets contain several missing values. The GPS positions are plotted by their Universal Transverse Mercator (UTM) coordinates. 


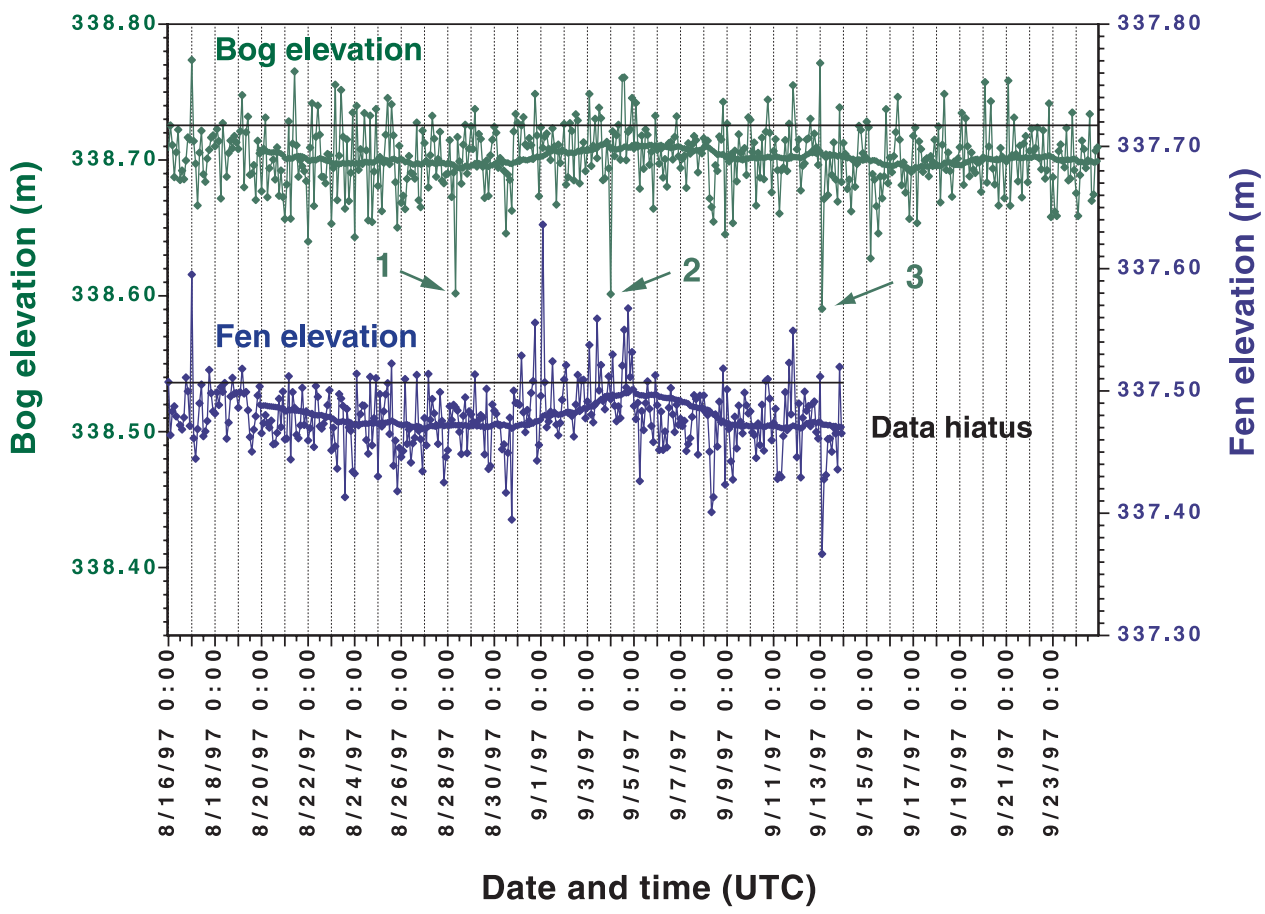

Figure 5. Surface elevations of the Red Lake bog and fen sites during a late-summer drought. Each symbol indicates the solution to a 20-min GPS-survey recorded every 2 hours. The 4-day (48 interval) moving average is indicated by the heavier line. The horizontal line marks the initial GPS elevation. Notice the three extreme low elevations at the bog site marked by arrows.

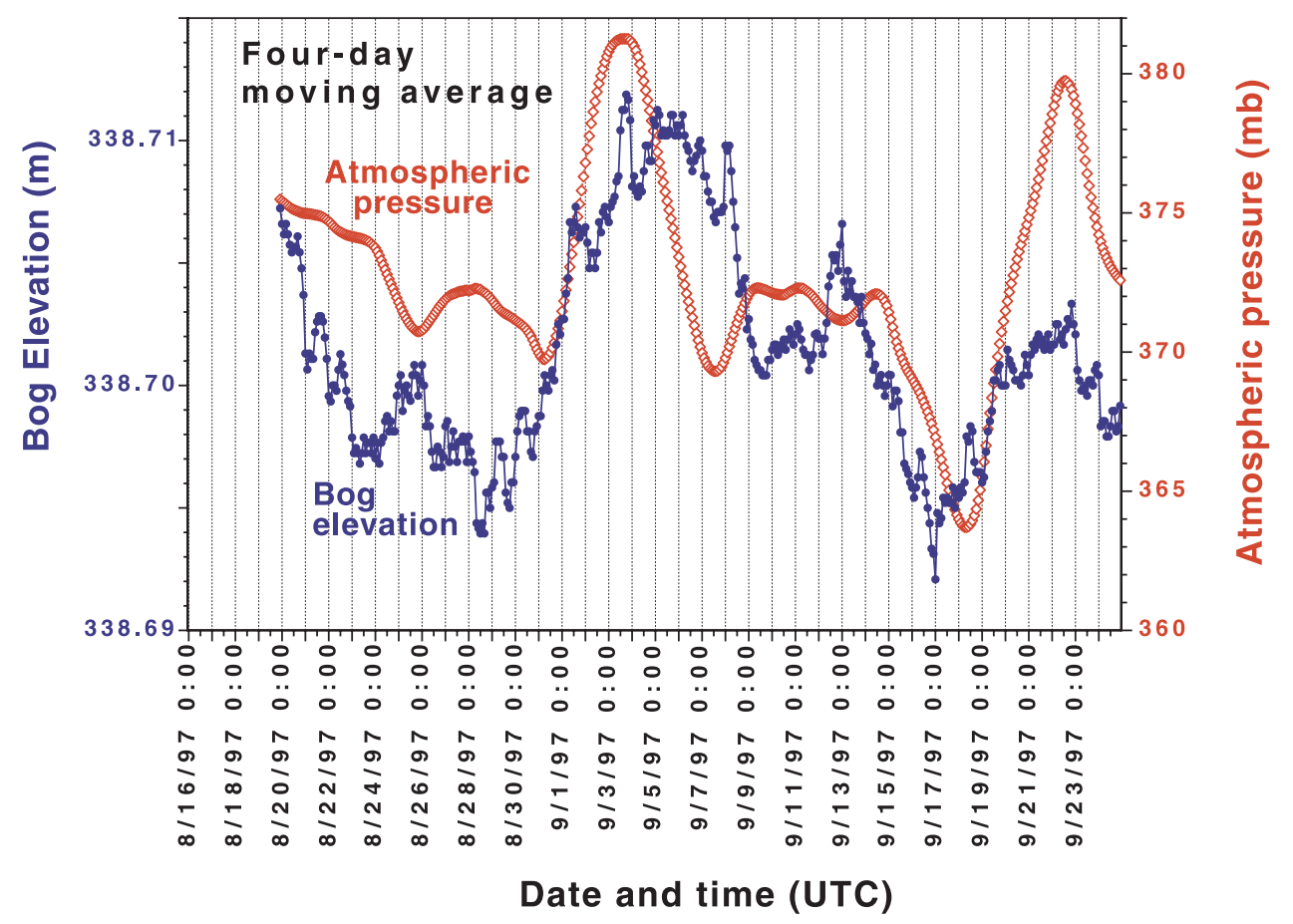

Figure 6. Four-day moving averages for atmospheric pressure and peat surface elevations at the bog site. Notice the greatly expanded scale for bog elevation and the narrow range of values $(<2 \mathrm{~cm})$. 

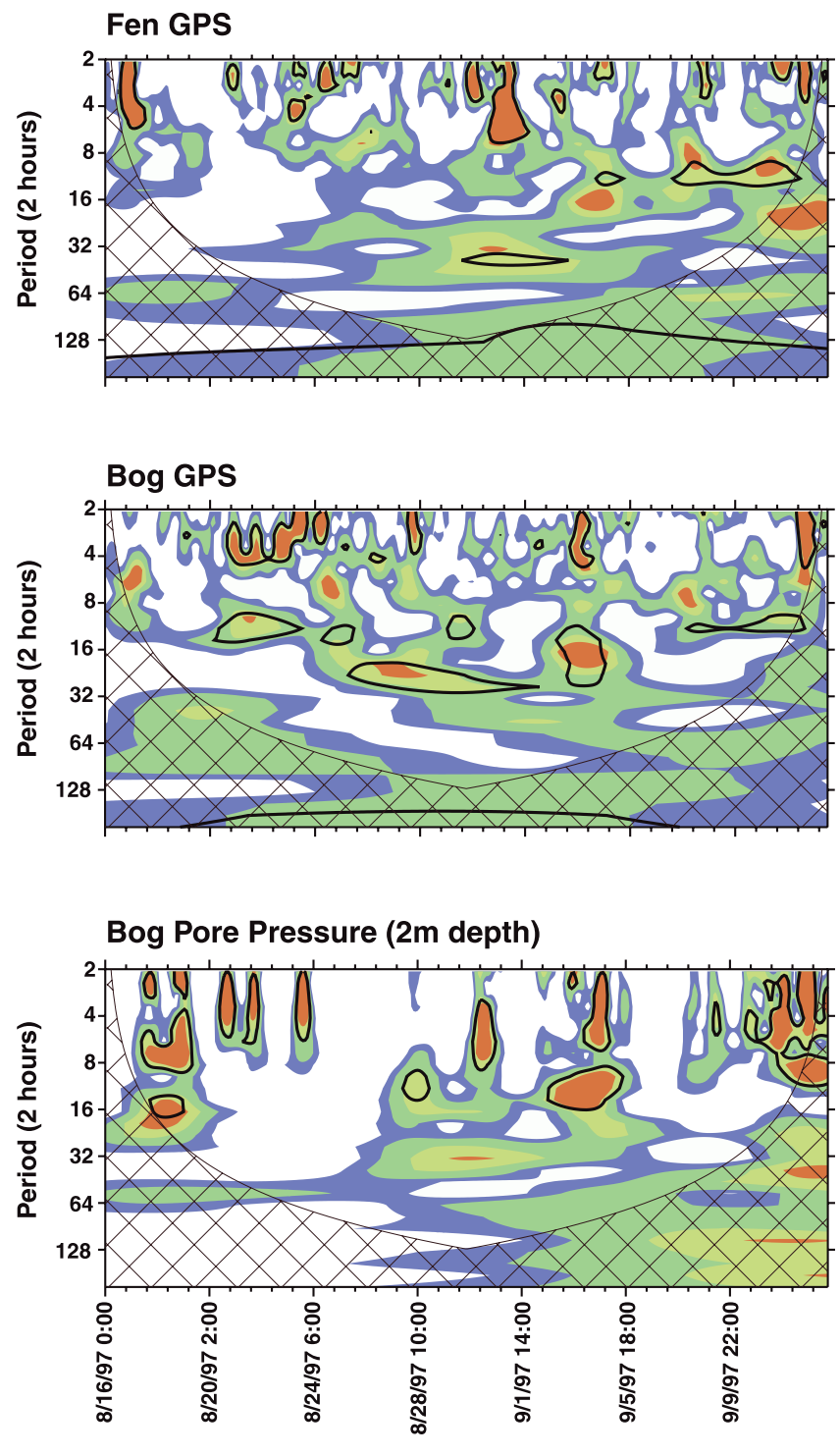

Date and Time (UTC)

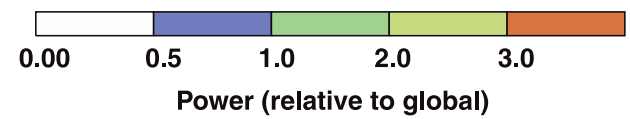

Figure 7. Wavelet power spectra for the late-summer GPS and bog-pore pressure data. The spectra show short, irregularly occurring cycles that are generally out of phase at the bog and fen sites. The contour lines indicate the $10 \%$ significance level for the red-noise band-pass filter, whereas the hatched pattern indicates the cone of influence where edge effects become important. 


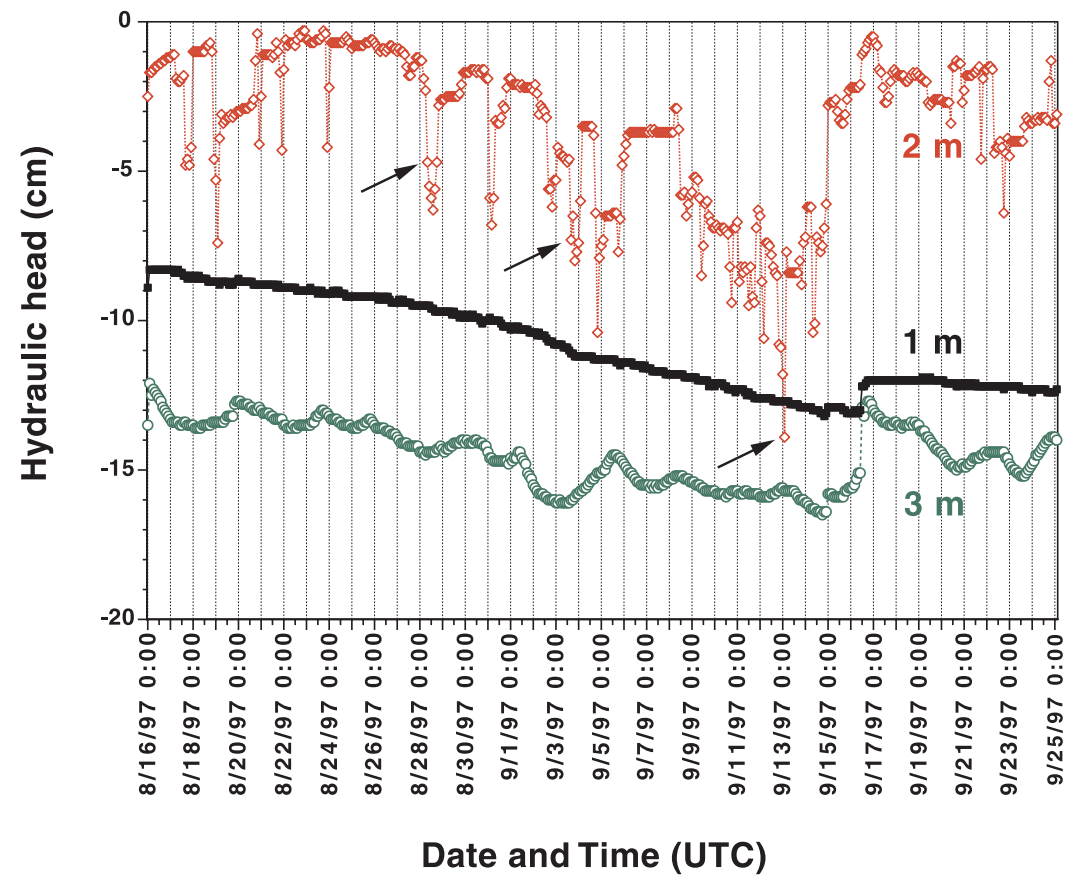

Figure 8. Hydraulic head (centimeters of head relative to the peat surface) collected every 2 hours at the bog site during a late summer drought. The arrows correspond to the timing of the three lowest GPS elevations. Notice the overpressure and short depressuring cycles at $2 \mathrm{~m}$ depth. Hydraulic head rose at all depths after a significant rainfall on September 16. 


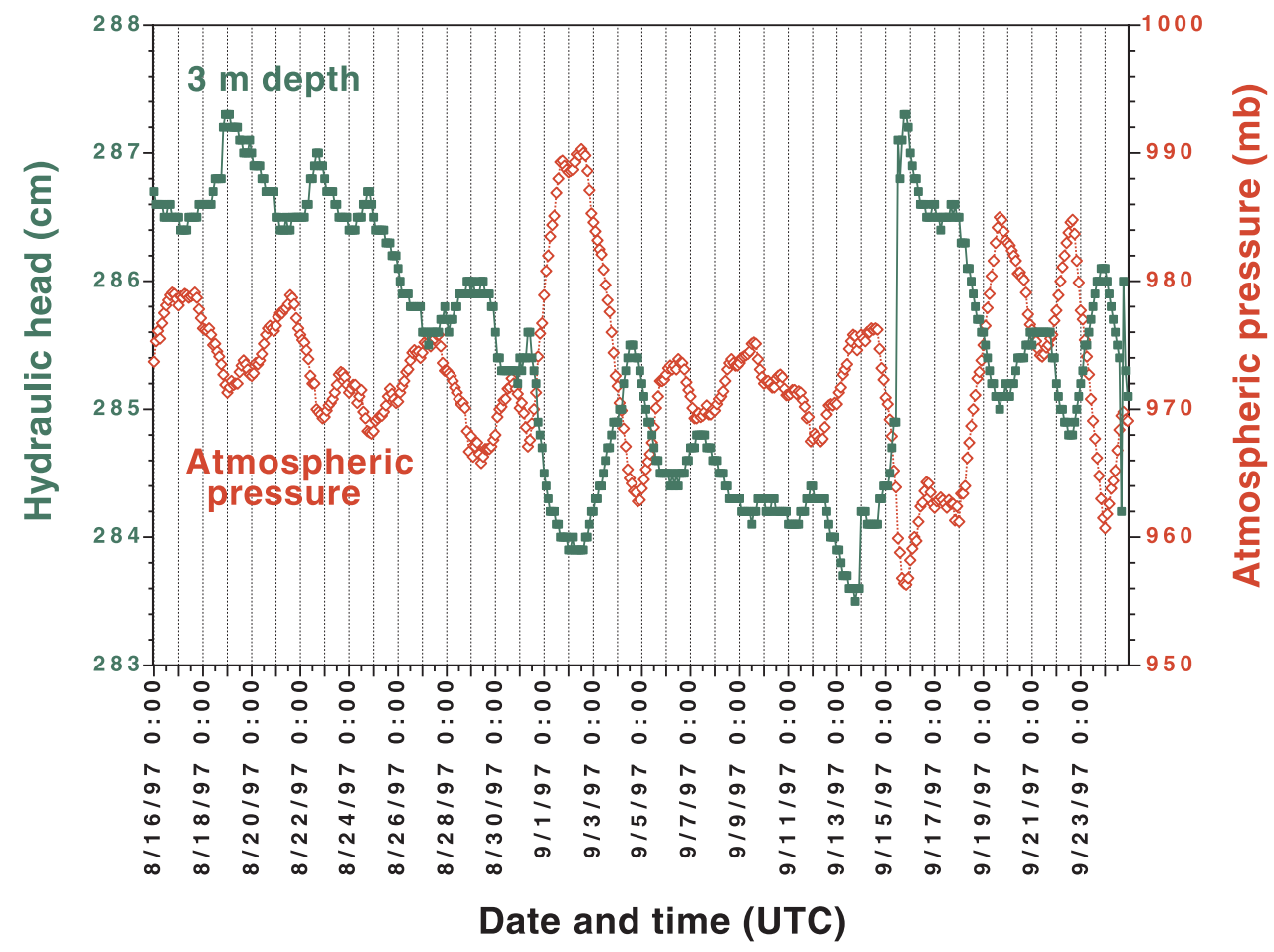

Figure 9. Inverse relationship between atmospheric pressure and hydraulic head at $3 \mathrm{~m}$ depth under the bog site. This relationship is typical of piezometers installed in confined aquifers. 


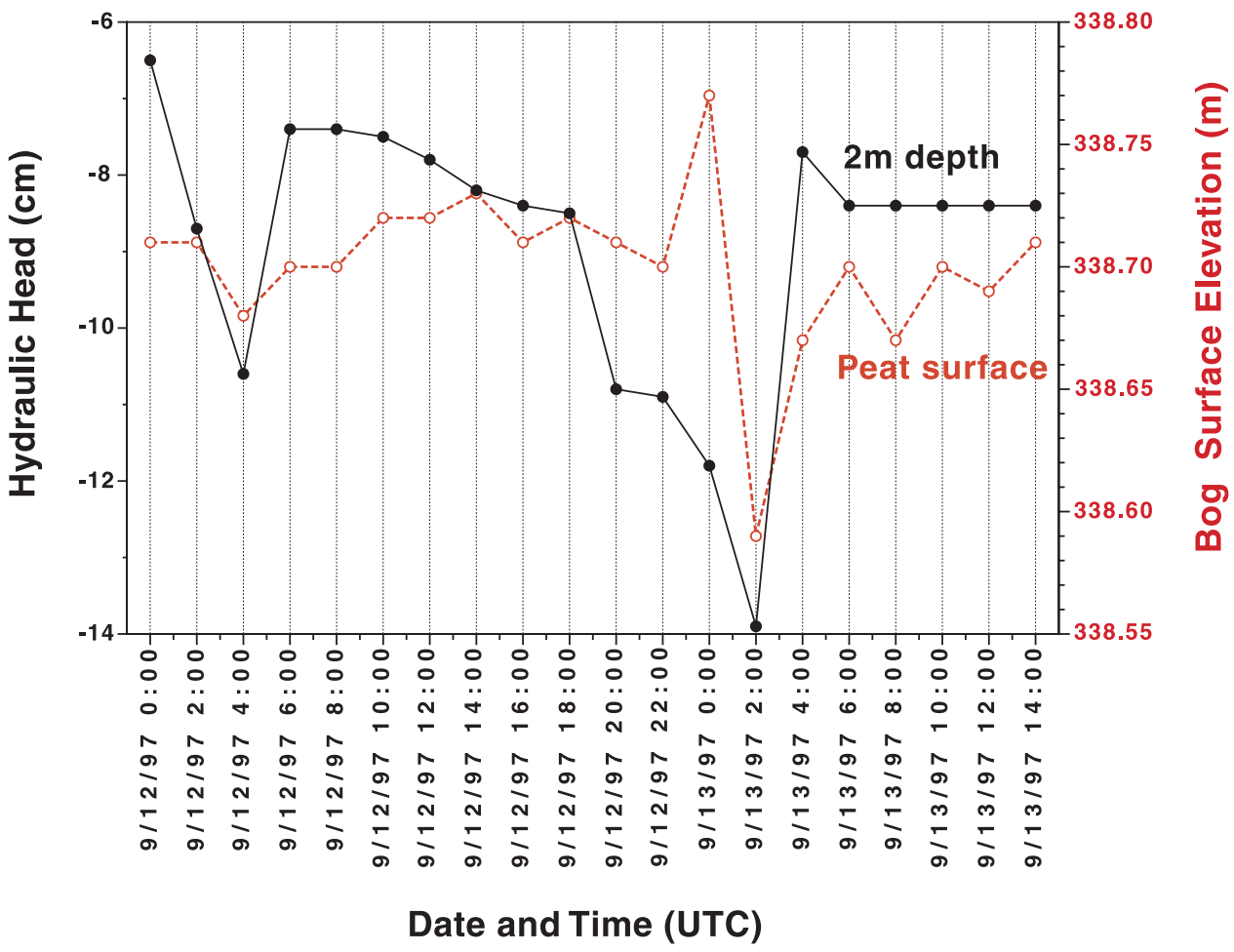

Figure 10. Synchronous changes in land-surface elevation and depressuring cycles at $2 \mathrm{~m}$ depth at the bog site. The large oscillations on September 13 were produced by the rise and escape of a bubble mass from the deeper peat followed by a rebound of the peat surface as pore waters moved laterally to fill the voids.

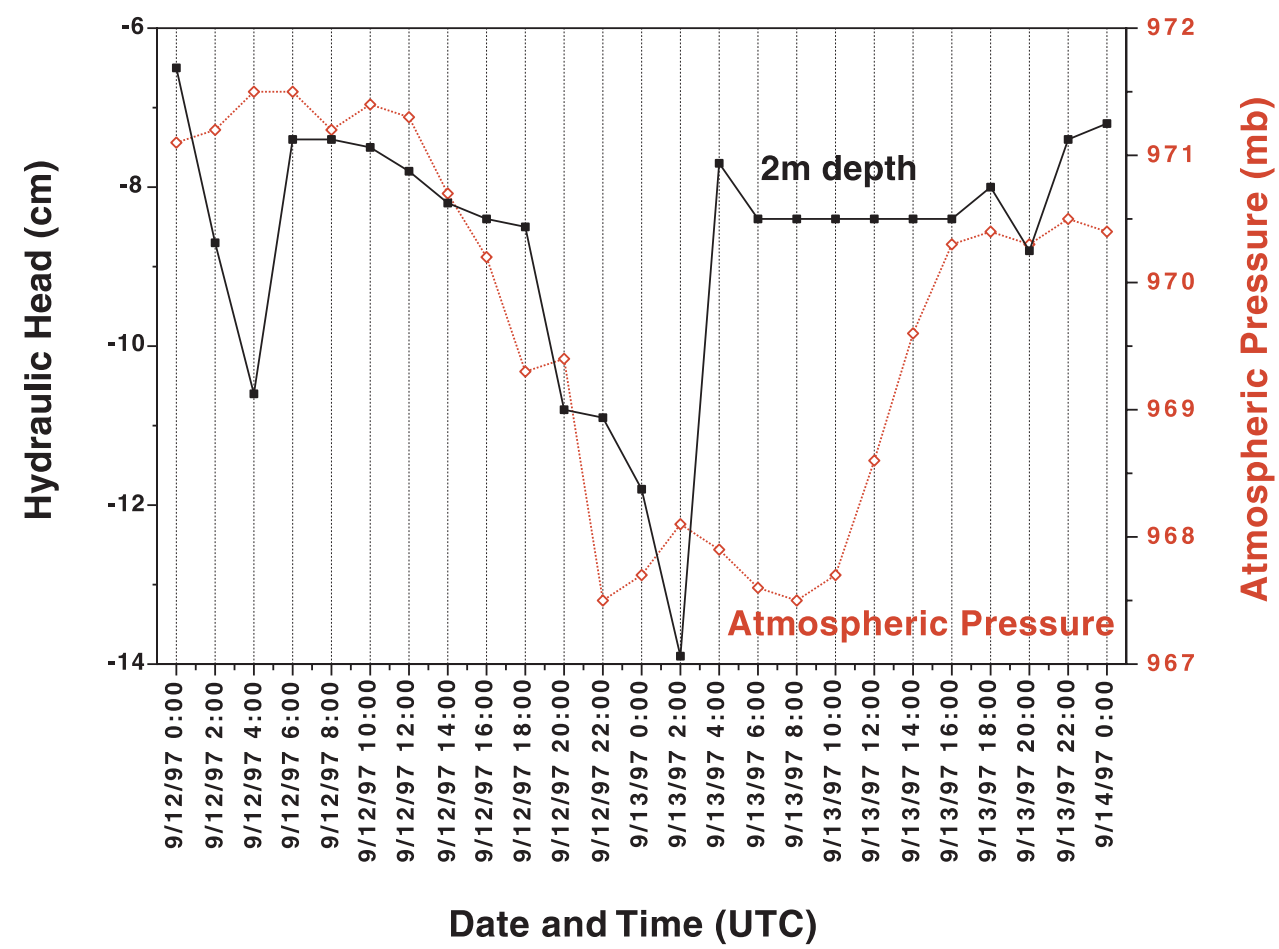

Figure 11. Synchronous changes in atmospheric pressure and depressuring cycles at $2 \mathrm{~m}$ depth at the bog site. The time interval is the same as that in Figure 10. 